\title{
On the Way to the Fluvial Anthroposphere-Current Limitations and Perspectives of Multidisciplinary Research
}

\author{
Lukas Werther $^{1} \mathbb{D}$, Natascha Mehler ${ }^{1,2}$, Gerrit Jasper Schenk ${ }^{3}$ and Christoph Zielhofer ${ }^{4, *(D)}$ \\ 1 Institute of Prehistoric and Medieval Archaeology, Department of Medieval Archaeology, \\ Tübingen University, 72070 Tübingen, Germany; lukas.werther@uni-tuebingen.de (L.W.); \\ natascha.mehler@uni-tuebingen.de (N.M.) \\ 2 Institute for Northern Studies, University of the Highlands and Islands, Kirkwall, Orkney KW15 1FL, UK \\ 3 Institute of History, History of the Middle Ages, Technical University of Darmstadt, \\ 64293 Darmstadt, Germany; gerrit.schenk@tu-darmstadt.de \\ 4 Institute of Geography, Leipzig University, 04103 Leipzig, Germany \\ * Correspondence: zielhofer@uni-leipzig.de; Tel.: +49-341-97-32965
}

Citation: Werther, L.; Mehler, N. Schenk, G.J.; Zielhofer, C. On the Way to the Fluvial AnthroposphereCurrent Limitations and Perspectives of Multidisciplinary Research. Water 2021, 13, 2188. https://doi.org/ $10.3390 /$ w13162188

Academic Editor: Brigitta Schütt

Received: 11 June 2021

Accepted: 4 August 2021

Published: 11 August 2021

Publisher's Note: MDPI stays neutral with regard to jurisdictional claims in published maps and institutional affiliations.

Copyright: (c) 2021 by the authors. Licensee MDPI, Basel, Switzerland. This article is an open access article distributed under the terms and conditions of the Creative Commons Attribution (CC BY) license (https:// creativecommons.org/licenses/by/ $4.0 /)$.

\begin{abstract}
Floodplains represent a global hotspot of sensitive socioenvironmental changes and early human forcing mechanisms. In this review, we focus on the environmental conditions of preindustrial floodplains in Central Europe and the fluvial societies that operated there. Due to their high land-use capacity and the simultaneous necessity of land reclamation and risk minimisation, societies have radically restructured the Central European floodplains. According to the current scientific consensus, up to $95 \%$ of Central European floodplains have been extensively restructured or destroyed. Therefore, question arises as to whether or when it is justified to understand Central European floodplains as a 'Fluvial Anthroposphere'. The case studies available to date show that human-induced impacts on floodplain morphologies and environments and the formation of specific fluvial societies reveal fundamental changes in the medieval and preindustrial modern periods. We aim to contribute to disentangling the questions of when and why humans became a significant controlling factor in Central European floodplain formation, and how humans in interaction with natural processes and other chains of effects have modified floodplains. As a conclusion, we superimpose emerging fields of research concerning the onset of the Fluvial Anthroposphere and provide 10 specific thematic objectives for future multidisciplinary work.
\end{abstract}

Keywords: preindustrial floodplains; fluvial societies; path dependencies; socionatural site; early anthropogenic forcing; natural and cultural heritage

\section{Introduction-Floodplains as Hotspots of Socioenvironmental Changes}

We understand floodplains as the natural area of a river system that is or has been characterised by episodic or periodic flooding during periods of higher discharge $[1,2]$. Floodplains comprise the active riverbed and palaeochannels, and roughly correspond to the distribution of Holocene flood sediments. Highly specialised river civilisations developed worldwide thanks to a specific mix of socionatural benefits and hazards. Floodplains and the associated alluvial landscapes represent some of the most dynamic parts of the cultural landscape and represent hotspots for natural and cultural heritage [3-5]. Although, at present, up to $50 \%$ of the world population live in natural or modified floodplains, these areas have been poorly investigated to date [6]. Little work has been undertaken to examine either buried archaeological remains within floodplain stratigraphies or the rich palaeoecological and geomorphological archives resulting from the excellent preservation conditions [7]. A deeper understanding of this highly sensitive spatial entity is of both scientific and public relevance, given the need-which is expected to become keener with climate change-for floodplain management $[8,9]$. 
Many floodplains have been hotspots of socioenvironmental dynamics and affected by significant anthropogenic modifications such as land reclamation and flood protection. These modifications could be so substantial that former floodplains are no longer recognisable. According to Tockner et al. [6], up to $95 \%$ of the Central European floodplains have been significantly modified or destroyed. Irrespective of the modification level, all floodplains and fluvial societies have been shaped by climatic and hydrosedimentary, as well as anthropogenic, impacts and interactions. Therefore, the questions are (1) whether the perception of specific floodplains and fluvial societies as forming a Fluvial Anthroposphere is justified, and if it is, (2) when particular Fluvial Anthropospheres come into being. To answer these questions successfully and to identify chronological as well as regional variants and similarities, the need to compare specific river systems has been underlined [10-12]. For this review, we focus on a comparative discussion of the onset of the Fluvial Anthroposphere in the three river systems of the Danube, Rhine and Elbe (Figure 1), which cover major parts of Central Europe and feature rather different natural (e.g., geology, hydrology, topography) and cultural (e.g., settlement and land-use history, technological traditions, forms of government) conditions.

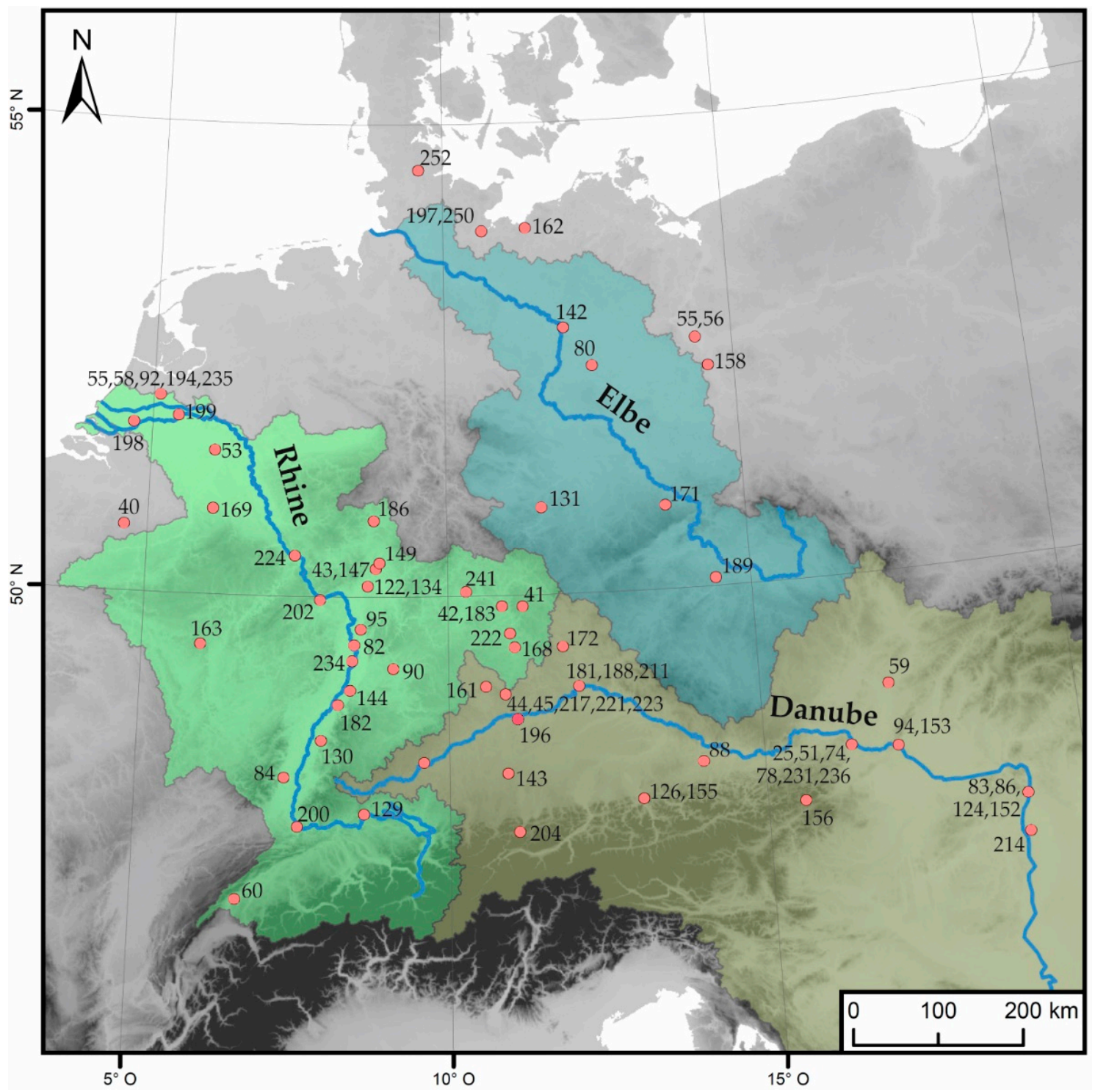

Figure 1. The Central European river catchments of the Danube, Elbe and Rhine with study locations, ranging from local to regional, mentioned in the text. The numbers refer to the list of references. 


\subsection{The Fluvial Anthroposphere in the Context of the Global Anthropocene}

Over the last decade, the Anthropocene has become a key scientific concept. It can be considered as a geological time scale that features significant and synchronous anthropogenic-induced changes in climate and material cycles, as well as species invasion and mass extinction at a global scale [13-17]. Further, socioecological perspectives in the humanities consider the Anthropocene a powerful new narrative that radically revises the 'meaning of nature and even the nature of humanity' [18]. However, the varied historical pathways to the Anthropocene as a global phenomenon ('Early Anthropocene', see [18]) are comparatively unexplored.

Worldwide, floodplains represent particularly sensitive socioenvironmental systems concerning anthropogenic impacts-with resulting effects on global freshwater balance [19] and land-use, aquatic and riparian biodiversity [20], material balances and greenhouse gas emissions. In contrast with the ubiquitous Anthropocene concept, anthropogenic forcing and the resulting feedback mechanisms in floodplains have to be considered as spatially and chronologically asynchronous. In this context, we understand the geomorphological, ecological and socionatural setting of anthropogenic forcing in specific floodplains on a more local-to-regional scale as a Fluvial Anthroposphere (Figure 2).

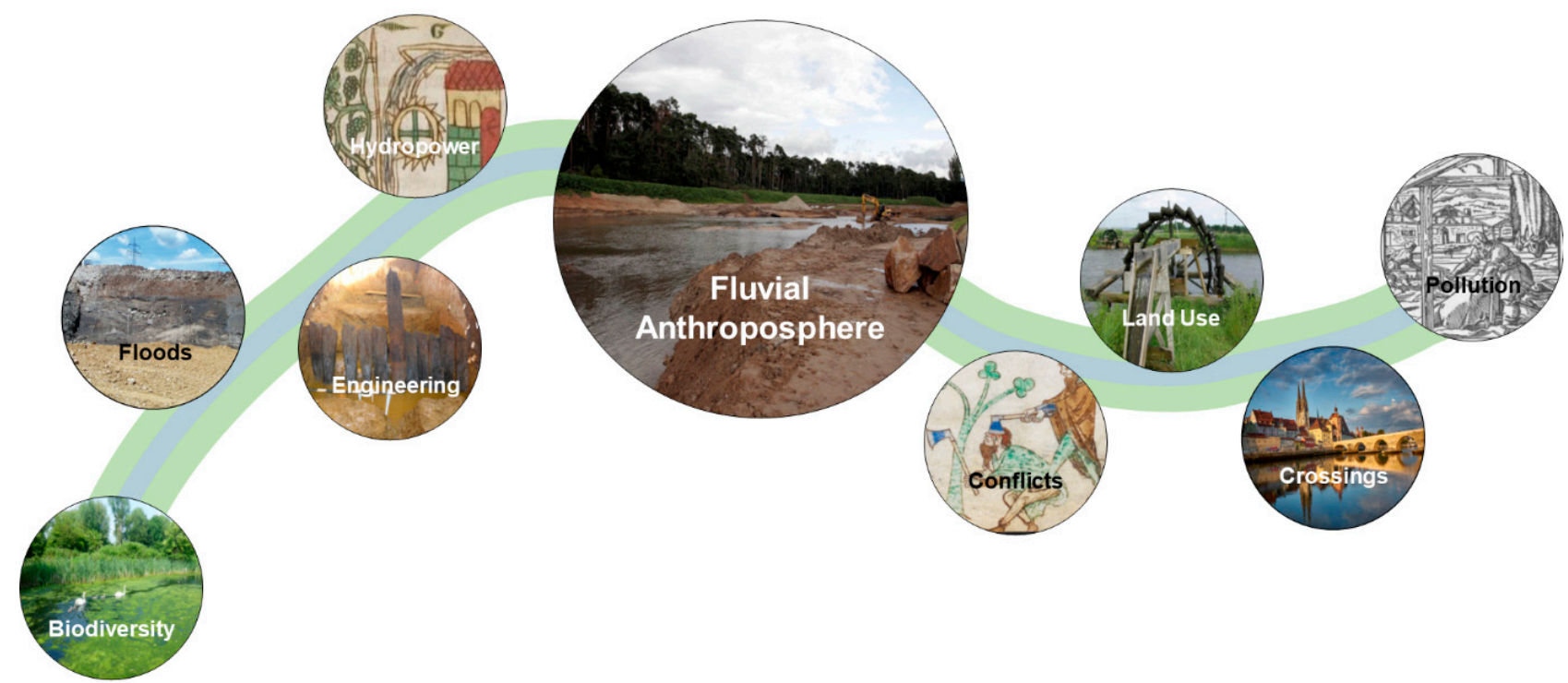

Figure 2. The Fluvial Anthroposphere as a series of socionatural processes in and along a floodplain. Thematic fields, such as the human impact on biodiversity, floods and flood-control measures, channel engineering, hydropower, legal frameworks and mechanisms of conflict management, land use and land reclamation, river crossings and floodplain pollution might have seen profound qualitative and quantitative changes during the medieval and preindustrial periods. Human-induced changes in floodplain environments and the formation of specific fluvial societies justify the understanding of Central European floodplains as a Fluvial Anthroposphere.

Here, increasing anthropogenic impacts can be traced through an artificial change in the magnitudes and frequencies of 'natural' processes. This includes flood hazards, sediment imbalance, chemical contamination and eutrophication. They can also be seen through the direct modification of 'natural' floodplain structures resulting from floodplain colonisation, water regulation and river fragmentation [21]. These processes run alongside changes in the involved socionatural systems and feedback mechanisms. Societies acted as agents of change, but were also shaped by the river systems in terms of their economic activities, sociopolitical structures and even their religious ideas. While most changes in natural processes can be measured by indicative measurements, the sociocultural factors required for changes can only be described relationally and determined semiquantitatively. The different search variables in the natural and sociocultural spheres are based on different material (e.g., sediments, pollen) and immaterial sources (e.g., ideas, norms, practices) and 
require a combined analysis of the archives of nature as well as of society. They enable a targeted search for the specific beginning, course and dynamics of the path to a Fluvial Anthroposphere in a given area of investigation.

The onset of the Fluvial Anthroposphere might be understood as a gradual transition from nature-dominated to human-dominated processes in floodplains [22], which is an integral part of the 'Early Anthropocene'. There are strong arguments for perceiving most Central European floodplains as having been a Fluvial Anthroposphere since at least the beginning of the industrial period. However, the human impact on many floodplains and the formation of specific fluvial societies began much earlier due to the long-lasting and intense cultural history in Central Europe [7,23]. In our review, we focus on the medieval and preindustrial modern periods as a game-changing time of transition, but we do consider both earlier and later developments depending on the specific floodplain. The onset of the Fluvial Anthroposphere is a global research desideratum due to the spatial and temporal asynchrony of the dynamics of fluvial societies [9,21]. However, there is a gap in the systematic availability and understanding of both the quantitative environmental and semiquantitative and qualitative socioeconomic parameters describing this great transition in a multidisciplinary way [24-26].

\subsection{Current Limits from the Fluvial-Geomorphological and Palaeohydrological Perspective}

European floodplain research has produced important geomorphological and geoscientific knowledge in recent decades. The International Union for Quaternary Research (INQUA) project 'Hydrological EXtreme Events in Changing Climate' [27], the radiocarbon chronologies of fluvial archives [28], the Deutsche Forschungsgemeinschaft (DFG-German Research Foundation) Priority Programme 'Changes in the Geo-Biosphere during the Last 15,000 Years' [29], the RheinLUCIFS project [30,31] and the DFG Graduate School on 'Paleoecosystems and History' [32] can be highlighted here (Table 1). In recent years, the potential of fluvial sediment sequences on shallow continental shelves for floodplain research has also been emphasised [33,34]. Accordingly, the long-term geomorphological development of Central European floodplains can be summarised as follows: covering early to mid-Holocene wetlands and secondary channels, the onset of loamy overbank deposition transformed floodplains in the course of the middle to late Holocene $[7,35,36]$. The onset and intensification of land use correspond with catchment-scale soil erosion and subsequent flood loam deposition [37,38]. Although this aggradation process differs between individual floodplains due to nonsynchronous catchment clearings $[39,40]$ and cascade effects $[29,41]$, flood loam deposition must be seen as a first, but indirect, human impact on floodplain evolution.

Direct human impact on floodplain evolution followed from the historical period onwards, characterised by a significant increase in hydroengineering constructions with weirs, dams, bridges and canals [42-46]. This process was accompanied by riparian forest clearings that are reflected in floodplain toponyms [47]. As shown by fluvial geomorphological studies, hydroengineering infrastructure such as watermills impacted floodplain morphology and stratigraphy due to its direct influence on river flood regimes and their hydrosedimentary connectivity $[43,48,49]$. Starting in the early 18 th century, channel engineering for navigation, flood protection and the prevention of avulsion represent a massive intervention in Central European floodplains as well [50-52].

The onset of overbank silt-clay deposition (German: 'Auelehm'), which often began in prehistory, is probably the most striking sedimentological marker of human impact in Central European floodplain history. However, this transition does not form the focus of our review report, as we aim to identify anthropogenic activities within the floodplain itself and their consequences, whereas the beginning of overbank silt-clay deposition was due primarily to catchment-scale intensification of land use and not human activity within the floodplain. Still, subsequent increases in the magnitude of overbank silt-clay deposition may be far more significant for the genesis of the Fluvial Anthroposphere [35,53]. These probable increases in fluvial dynamics need to be explained through multidisciplinary 
research into human activities within the floodplain and are far less researched. Similarly, although numerous medieval and early modern construction works led to changes in flood regimes, little work has done on these mechanisms to date.

\subsection{Current Limitations from an Archaeological Perspective}

Central European floodplains are key areas of cultural heritage, and the archaeological preservation is often exceptional, but this heritage is constantly being destroyed [5,54]. In recent decades, several multidisciplinary projects have focused on archaeological remains at a river-catchment scale, but rarely in the floodplain itself and very few projects have on the late medieval and postmedieval periods. The cutting-edge project 'Mensch und Umwelt im Odergebiet in ur- und frühgeschichtlicher Zeit' [55,56], which dealt with the socionatural interplay from the Neolithic to the early medieval period, concluded that human impacts on the environment were mostly apparent from the late medieval period onwards. Other projects have focused on isolated river sections or periods such as the lower Rhine River [57,58] or the March River in the 1st millennium AD [59]. There are local case studies that yield spatially restricted insights into floodplain modifications [60-62]. However, attempts to make a cross-catchment synthesis of archaeological features in floodplains are rare [63]. Furthermore, documentary sources (e.g., texts and old maps) have rarely been investigated in a systematic way to complement and contrast the archaeological record.

As far as we know, the initial exploitation of European floodplains 'in their natural state' for grazing and the use of aquatic resources dates back to prehistory. In the Roman and early post-Roman periods, floodplain modification for drainage and navigation, among other purposes, is mainly documented at the local scale. However, it is only from the medieval period onwards that large-scale landscape engineering and systematic floodplain reclamation can be observed in many catchments [64-66]. Embankments, dykes, artificial channels, milldams, fishponds and weirs, bridges and systematic levelling and waste disposal from this era are typically encountered archaeological features $[9,62,67-69]$. The impact of these anthropogenic features on floodplain sedimentation and fluvial morphodynamics has been discussed $[43,49,70]$, but the features themselves have rarely been the target of specific research, so they usually serve to tell a rather simplistic background story. This follows from the fact that research-focused excavations are generally rare and the archaeological potential to enhance our understanding of past floodplain transformation remains unexplored. This is especially true for the later medieval and early modern periods. Furthermore, the archaeological perspective has often been too narrow, neglecting to pay closer attention to ecological and hydrological consequences and feedback loops.

\subsection{Current Limitations from an Historical Perspective}

From the historical perspective, river history is a classic topic. The historiography has evolved from the early study of the Rhine by the annalists [71] to an 'histoire totale' in the longue durée [72], the 'urban history' of rivers [73-75], the economic and environmental history of rivers [76-78] and the history of the network of rivers and canals as transport routes and infrastructure [79-81]. Increasingly, interest has been focused on the floodplains of the great European rivers [82-86]. Regional studies have examined environmental dynamics and human activities in river deltas, fens, swamps and lagoons [87-90] from England [91] to the Netherlands (as an 'amphibious culture' [23]) to the Venetian lagoon [92].

However, analysing rivers in the sense of environmental history as resources, sociotechnical drivers and specific habitats $[91,93,94]$, focusing on floodplains as cultural landscapes and studying rural societies shaped by the waterscape, represent new directions in academic research [6,10]. Scholars are asking questions about groups of actors and the agency of increasingly specialised professions (e.g., millers, tanners, engineers) in transforming the landscape, and the conflicts that these have created [95]. In recent years, a methodological consensus has been suggested, whereby the common history of rivers and society is analysed not as a dichotomy of nature and culture, but as the complex interplay within a specific 'socio-natural site' $[4,25,51,96,97]$. This means a reciprocally working 
combination of natural and anthropogenic structures resulting from long historical processes of interaction between nature, technology and society, which shaped the floodplain specifically as an instance of colonised nature $[98,99]$. However, many questions regarding the onset of and the way towards the Fluvial Anthroposphere remain unanswered due to the underdeveloped interplay between natural science and the humanities: Which natural and human-induced material flows, interactions, feedback loops, tipping points and cascade effects have to be considered? To what extent do these dynamics reflect human intentionality and to what extent do they not? As a research perspective, there is now the unique opportunity to combine the recent spatial and material turn of cultural studies with the cultural turn of natural sciences in a meaningful way [8,100-102]. Moving beyond the old and simplistic theses on hydraulic societies [103], a more bottom-up approach is proving to be promising, helping to conceptualise the interplay of society and nature as a kind of 'empowering interaction' [84,104], which led to epoch- and space-specific cultural landscapes. This requires close multidisciplinary cooperation.

\subsection{Research Perspectives within a Multidisciplinary Framework}

Beyond the disciplinary limitations outlined above, we aim to highlight multidisciplinary research perspectives with regard to Central European floodplain development:

(a) Mills, fisheries, irrigation, draining, levelling for land reclamation, bridges, pathways, dykes and artificial channels have immediate effects on floodplains. The use of floodplain resources such as water, gravel, fish, wood and meadows also led to significant modifications to floodplains. Anthropogenic features in the floodplain are rarely isolated, but always entangled with and embedded in natural features and processes. Therefore, they have been defined as a 'fluvio-cultural unit' that forms a complex structure. Small changes can initiate 'path dependencies' that shape the development of a floodplain into its modern-day state $[9,10,12,76]$. This is exemplified by the considerable impact of medieval milldams on recent hydropower potential $[7,105]$. However, precisely when and why human activity became a significant controlling factor in specific floodplains, and how socioeconomic structures were influenced by riverine environments, has not yet been examined in a multidisciplinary and comparative way $[8,9,25]$. A particular deficit regards the long-term socioecological perspectives, which would not only aim to understand the environmental and geomorphological history in the floodplain, but also the inherent changes within the corresponding societies.

Macklin and Lewin [11] use the term 'river civilisation', and they and others [106-109] have called for multidisciplinary research that includes historical approaches across domains. However, the impacts of the fluvial environment on societies have not really been highlighted to date. These are of particular importance, because the highly dynamic interaction has produced very specific socioecological systems in many areas, and fluvial or even amphibious cultures and societies $[23,47,110]$, the members of which have both extensively adapted their way of life to the particular conditions in and around floodplains and intensively altered those conditions. On a granular level, however, it is often unclear how social activities at the local, regional and supraregional scales influenced or even excluded each other. These are key issues for understanding of the formation of the Fluvial Anthroposphere as a network of effects of floodplain and society in a socionatural site (Figure 3).

(b) Knowledge of natural palaeohydrological conditions underpins any attempt to pinpoint the transition towards the Fluvial Anthroposphere. This means that even if the palaeohydrological focus of floodplain research relates to the medieval and preindustrial modern period, the full Holocene floodplain history needs to be considered in order to identify and quantify anthropogenic changes. In this context, geoscientific floodplain research approaches must develop quantitative parameters and related Holocene boundary levels. These parameters will be useful for past and current socioecological risk assessments in the context of the Anthroposphere debate and current Global Change [16,17,19,24,111-113]. 
(c) The transition from nature-dominated to human-dominated processes can be detected in many environmental archives for the historical period $[17,22]$ and there are indications from fluvial archives as well $[26,114]$. The detection of 'natural' climatic imprints within fluvial archives will help to distinguish between climatic and anthropogenic forcing mechanisms in floodplain genesis. Here, signals of Holocene 'Rapid Climate Changes' (RCCs) [115-118] within floodplain chronostratigraphies play a key role. The most recent RCC is known as the 'Little Ice Age', for which Central European lake-level reconstructions [119] point to wet intervals. However, although late Holocene flood loams might also have an extraordinarily high potential for the detection of climate-induced flood periods $[120,121]$, those of Central European floodplains are still under-investigated.

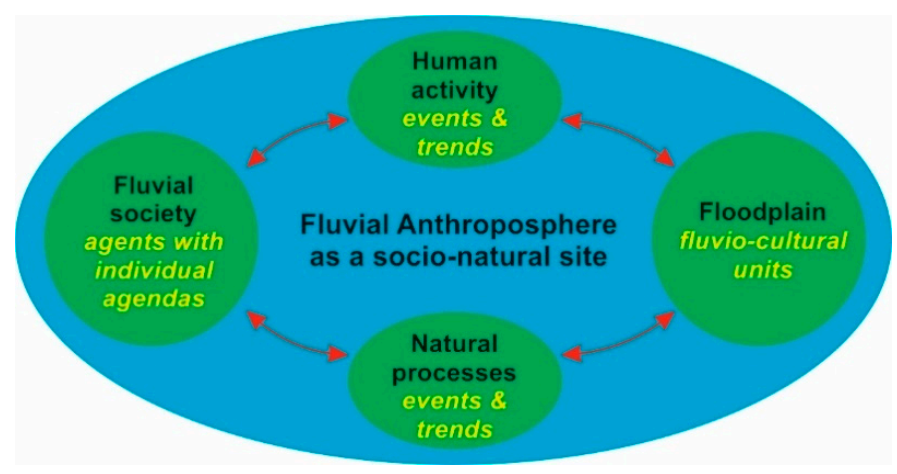

Figure 3. The Fluvial Anthroposphere as a socionatural site.

Table 1. Joint research projects mentioned in the text.

\section{Joint Research Project}

Hydrological EXtreme Events in Changing Climate

Changes in the Geo-Biosphere during the Last 15,000 Years

RheinLUCIFS

This INQUA-funded project aimed to reconstruct past and supraregional hydrological activity in the context of climatic variability using an approach based on a meta-analysis of data sets of chronological control $\left({ }^{14} \mathrm{C}\right.$ and luminescence dating) $[27,28]$.

The DFG Priority Programme aimed to reconstruct environmental conditions and geomorphological processes in Central Europe by combining catchment-scale case studies [29].

The RheinLUCIFS project investigated the effects of land use and climatic forces on sediment fluxes at Rhine catchment and subcatchment scales [30,31].

Paleoecosystems and History

The Regensburg Graduate School on 'Paleoecosystems and History' aimed to reconstruct historical human-environmental interaction in Germany [32].

The DFG Priority Programme 1630 aimed to construct a complex

Harbours from the Roman Period to the Middle Ages understanding of Roman and Medieval harbour systems in Europe and their ecological, logistical, economic, social, legal, military and religious subsystems $[44,45]$.

Mensch und Umwelt im Odergebiet in ur- und frühgeschichtlicher Zeit

This project of the Volkswagen Foundation investigated socio-natural interplay along the River Oder from the Neolithic to the early medieval period $[55,56]$.

The Dark Ages in an interdisciplinary light: people, landscape and climate in the Netherlands between AD 300 and 1000

This project, funded by the Netherlands Organization for ScientificResearch, aimed to reconstruct the Dutch riverine landscape and its human occupation in the first millennium $\mathrm{AD}$ [58].

ENVIEDAN. Environmental history of the Viennese Danube 1500-1890

This project, supported by the Austrian Science Fund investigated the long-term dynamics, patterns and side effects of the colonisation of rivers, focusing on the Viennese Danube [25,51].

Historical disaster research with a view to comparative cultural study

This DFG project undertook an historical investigation of disasters such as flooding and droughts [84]. 


\section{Specific Thematic Fields and Major Challenges}

We now present 10 specific thematic fields that we identify as critical to the understanding of the transition to the Fluvial Anthroposphere in Central Europe.

\subsection{Construction, Maintenance and Socio-Natural Effects of Flood Control Measures}

Ice drift, disastrous floods [122], channel displacement [123] and droughts [95,124] have a remarkable impact on fluvio-cultural units [125]. Riverine societies have developed techniques to control and exploit extreme events and protect (agri)culture from floods: damming, river straightening and canalisation $[42,52,69,79]$, drainage systems and plantings against erosion [87,90]. Situations in the upper courses of rivers [93] and on smaller rivers, for which the term 'flood culture' has been suggested, seem to be particularly dynamic [126]. Additionally, disastrous 'normal' flood events have been the focus of research in recent years [86,87,127-131]. An initial interest in reconstructing such events and the perception and interpretation of them has shifted the examination of topics such as coping strategies, societal learning from recurring flood events and river management practices $[85,89,132,133]$. However, the relationship between extreme events such as floods, long-term structural changes due to hydro-climatic fluctuations and societal adaptation strategies has only recently been questioned [134]. Furthermore, there is a lack of systematic and comparable studies on different river systems and sections, especially for second- and third-order tributaries (e.g., Neckar, Main, Havel, Altmühl), for which we have a poor knowledge of adaptation strategies, preparedness and prevention during different periods of sociocultural transformations and climatic change.

\subsection{Long-Term Social Responses to Changing Flood Dynamics}

The responses, adaptions and varying vulnerability of riverine societies to hydrological changes have been globally recognised $[132,133,135,136]$. In the context of long-term riverine changes, the coupling of robustly dated floodplain chronostratigraphies [110] and medieval place names enables an understanding of the impact of longer-term floodplain dynamics on society [47]. Place names provide information on the values, constraints and threats of water over time and across space [137-139]. However, regarding long-term periods of up to several centuries, our knowledge of the societal responses to hydrological changes is still scarce, although it is known that climatic changes modified flood regimes, floodplain surfaces and floodplain ecosystems, bringing about, for example, the emergence of malaria $[140,141]$, which influenced accessibility to fluvial wetlands before c. 1000 AD.

\subsection{Floodplain Land Use and Modification of Riparian Vegetation}

Floodplain palaeoecological studies show a rich biodiversity during phases of low anthropogenic impact, consisting of habitats that have become very rare in temperate Central Europe [142], e.g., fens in fluvial settings [143] and large oak-rich riverine woodlands [144]. Early and middle Holocene floodplains were densely forested with birch (Betula), willow (Salix), poplar (Populus), alder (Alnus) and oak (Quercus) [7,144-146]. Due to intensified land use in the catchments, flood loam deposition led to a shift from multichannel rivers towards late Holocene single-channel and meandering rivers [7]. This indirect human impact on floodplain habitats started at different regional times [39], but ultimately corresponds with more homogeneous floodplain morphologies, a reduction in riverine biodiversity and a significant decrease in Quercus-Ulmus-hardwood floodplain forests [29,147]. Regarding the onset of direct human impact, river systems are important natural corridors for the distribution of arable plants. The edges of floodplains may be among the oldest agricultural areas in the world [148]. Riparian forest clearings, pastoralism and meadow cultivation are detectable in middle to late Holocene pollen records from Central European floodplains $[144,149]$. The establishment of managed water meadows is one of the additional remarkable human impacts [150]. 


\subsection{Effects of Fishing and Hunting}

Worldwide, river ecosystems have seen the largest decline in large vertebrates [20], with the human threat to biodiversity emerging long before the modern period. Despite legal regulations from the medieval period onwards, overfishing, pollution and hydroengineering have resulted in a dramatic decline of the allis shad ('Maifisch', Alosa alosa) in the Rhine, as well as the sturgeon family ('Stör/Europäischer Hausen', Acipenseridae) in the Danube [151-153]. Written sources, artefacts and environmental data have been studied to investigate the exploitation of such riverine fish species, but rather sporadically and not from a cross-disciplinary perspective. Additionally, modern scientific approaches such as aDNA analyses are still infrequently employed [154]. Furthermore, changes in fish communities were mainly reconstructed for the modern period, without utilising archaeological material from earlier periods [94,155]. Medieval fish remains are rarely utilised and interdisciplinary syntheses contributing to fish ecology hardly exist. Human intervention in riverine ecosystems (hunting, habitat drainage, clearances) also has significant impacts on other wild animal species, such as the European pond turtle (Emys orbicularis) [156] and beaver (Castor fiber) [157,158]. A challenging issue is the mismatch of source categories. Mentions of fish weirs and traps are abundant in written sources from the early medieval period onwards [159]. However, there is only very limited archaeological evidence for them in floodplains $[160,161]$. Hence, the hydro-sedimentary effects of such installations remain largely unknown, and our knowledge of conflict associated with their use is patchy $[10,63]$. Archaeological research on fishing and its ecological effects or on the impact of hydraulic structures (mills, dams, etc.) on fish migration and populations of both fish and wild animals is hampered by the scarcity of scientific wetland excavations utilising on- and off-site methodologies of a good standard.

\subsection{Construction, Maintenance and Hydro-Sedimentary Effects of Mills and Hydropower Installations}

Hydropower installations with water wheels, ponds, diversion channels and dams had a significant impact on sediment flux, flow rate, water temperature, groundwater tables and fish migration, as well as navigability $[10,36,43,52,162]$. In the early medieval period, vertical undershot constructions with no need for large dams prevailed in Central Europe [163]. After a fundamental transformation from the 11th-12th centuries onwards, overshot wheels requiring large-scale damming and water-table modifications had significant geoecological effects on floodplains $[164,165]$. Hydro-energy was now frequently used for many craft purposes and instead of mainly for grinding grain. There are clear signs of a significant rise in the numbers of mills, as well as a spatial diffusion and relocation. Large numbers of mills clustered in small urban and monastic areas, accompanied by significant modifications to the primary riverbed $[43,139,162]$. These changes have been ascribed to the 'medieval industrial revolution' [166,167], a concept that requires reassessment. A second period of intensification and differentiation, accompanied by serious water pollution, can be observed in the 15th-16th centuries, when, for example, paper mills spread all over Europe [168]. However, our knowledge of the complex interplay between hydro-energy exploitation, fluvial and ecological feedback (e.g., sediment flux, fish populations), socioeconomic transitions and long-term path dependencies $[105,169]$ is still patchy. From the historiographic and archaeological perspectives, late and postmedieval installations have been rather neglected. Further, the choice of locations in the context of competing interests in floodplains has never been analysed in a comparative and diachronic way.

\subsection{Floodplain Pollution from Craft, Manufacturing and Mining}

Mining, craft and floodplain colonisation have led to floodplain pollution, eutrophication, changes in aquatic biodiversity and social responses worldwide [20,21]. Historic mining has been one of the most far-reaching human interventions in European river systems since at least the Middle Ages [21,170]. Mining activities were carried out alongside large-scale forest clearing [171]. As a result, preindustrial flood loam aggradation 
and floodplain pollution occurred [107,172,173]. Floodplains served as a depository for inorganic and organic pollutants, which were rich in nitrogen, phosphorus and heavy metals $[174,175]$. From the 13th century onwards, one can observe an awareness of water pollution in floodplains and various attempts to reduce this pollution. The problem of how and where to dispose of effluents became a major topic of legislation $[176,177]$. Despite a few sophisticated exceptions (e.g., isotopic tracers [178], multi-tracer approaches [179]), there is a lack of systematic and comparative research on pollution processes within fluvial sediments, and previous studies lack ground-truthing and detailed consideration of a socionatural variety. Although major sources of pollutants, such as mines and tanneries, are well known, it is difficult to assess their contribution to pollution [10,172]. Furthermore, path dependencies and the effects on biotic subsystems have been rather neglected [180].

\subsection{Construction, Maintenance and Socionatural Effects of River Crossings}

Ferries, fords and bridges are essential elements of floodplains [181-183], but there is a great need for further research, especially from a historical perspective [74]. All river crossings have impacted floodplains, not only in terms of solid built structures but also as a mobile and connective element of societies in and on rivers. Bridges have been studied as an important part of the built infrastructure, as well as a factor for cultural, economic and political life [184-187]. Outstanding examples, such as stone bridges, have been comprehensively examined [188], although usually from a disciplinarily limited focus $[189,190]$. As multifunctional sites for punishments, markets and defensive facilities, the number of specific studies is high, but only a few multidisciplinary studies [191] have considered the effects of river crossings as a formal element for the artificial fixation of watercourses, as a compulsory point for settlements, or in terms of path dependency from a ferry to a bridge. Furthermore, the financing and maintenance of expensive bridges has also been poorly examined in relation to the possible climatic impacts ('bridge death' [134,192]).

\subsection{Construction, Maintenance and Hydro-Sedimentary Effects of Land Reclamation}

Human interventions in floodplains include draining and embankments for land colonisation or animal husbandry. From the 11th to 12th centuries and onwards, [193,194] drainage measures increased [195]. During the 18th century, large-scale land reclamation measures ('ameliorations') were introduced, e.g., in the Donaumoos, which coincided with significant ecological changes [196]. Opposition to drainage evolved from irrigation (e.g., floodable meadows), which was widely overlooked as a feature of premodern European floodplain management $[90,150]$. Although scattered projects to rural land reclamation have been carried out, multidisciplinary approaches are infrequently employed. Especially in the late medieval and early modern periods, knowledge of ecological and sociocultural consequences and feedback loops remains limited.

Regarding urban land reclamation in floodplains, archaeological findings point to a tipping point around 1200 A.D., with a high number of large-scale construction schemes, which are not usually documented in written sources. An outstanding example of this is Lübeck, where, in the early 13th century, the urban settlement expanded into the Trave floodplain [197]. Similar transformations have been seen in the Rhine river system, all dating to the 12th and 13th centuries [198,199]. Such modifications were sometimes ended with flood catastrophes [200]. There is a general lack of comparative analyses of urban land reclamation schemes and their corresponding socio-natural impacts. Municipal administrative records, iconographic sources and maps have rarely been used to answer the questions of who initiated, financed and coordinated urban land reclamation in floodplains.

\subsection{Environmental and Socioeconomic Effects of Channel Engineering and Inland Navigation}

Inland navigation from antiquity to the High Middle Ages has recently been studied quite thoroughly, especially as part of the DFG Priority Programme 1630 'Harbours from the Roman Period to the Middle Ages' [63,201,202]. However, the impacts of navigation and rafting on the fluvial landscape from the 13th century onwards are rather unknown, 
despite the higher number of available sources [4,203-205]. Many river sections were not suitable for navigation or rafting due to natural (e.g., cataracts) and man-made (e.g., dams and weirs) obstacles, resulting in frequent conflicts of use. Decisions enhancing or degrading trafficability often implemented long-lasting economic, social and environmental path dependencies $[10,165]$. From the 11th to 12th centuries onwards, canalisation, bank revetment and river diversion, as well as the extraction and dumping of a ship's ballast, transformed European floodplains on a hitherto-unseen scale [65,162,206-208], embedded in the complex interplay between exploitation rights, exploitation interests and material legacies $[25,52,165,209]$. There is much archaeological proof of stream works and, from the 14th century onwards, written and pictorial sources do also allow for further insights, but they have hardly ever been analysed systematically $[49,67,210,211]$. The dynamics and socio-natural consequences of medieval and early modern stream engineering have been neglected by multidisciplinary research, and the path dependencies are unknown.

\subsection{Legal Framework, Power Structures and Conflict Management in the Context of Floodplain Use}

Floodplains have been spaces of overlapping and competing rights and interests arising from the connection between the changeability of the fluvial landscape and the need for perpetual readjustments to the legal framework, individual rights and claims [212]. Major conflicts are documented between groups of agents, for whom a continuous water flow has been essential (e.g., shipowners) and groups for whom damming has been desired or inevitable (e.g., millers). Further conflict lines have been between those in need of watercourses for waste disposal (e.g., tanners) or for clean water (e.g., brewers), as well as between agents with a high general water demand $[10,87,126,165,212,213]$. Land loss due to shifting channels has been another major cause of conflicts [205]. Since watercourses form territorial borders, they have been the subject of power conflicts [214]. From the 12th to 13th centuries onwards, we can observe the development of highly specialised water rights and fluvial confraternities [215]. In the Late Middle Ages, guild orders of fisheryand floodplain-related craft contributed to specifications in legal frameworks [52,176]. However, a comparative and cross-period analysis of floodplain-specific interest groups, rights, orders and codifications as part of a socio-natural site is a challenging undertaking. Consequently, the spatial distribution and overlap of different interests, and the specific conflict potential within individual sections of rivers, has not been analysed in the longue durée [63].

\section{Methodological Challenges}

In this review, we identify several methodological challenges that are critical to understanding the transition to the Fluvial Anthroposphere.

\subsection{Advances in Geophysical Prospection Techniques and Remote Sensing in Fluvial Geomorphology and Geoarchaeology}

Floodplain chronostratigraphies with intercalated human-influenced deposits are suitable archives for the reconstruction of cause-effect mechanisms in socio-natural systems [216]. Floodplain deposits are valuable geoarchaeological archives, because anaerobic conditions foster the excellent preservation of palaeoecological and geomorphological proxy parameters, and of archaeological remains [217]. However, floodplain stratigraphies also present difficult exploration conditions that require complicated and costly excavation techniques due to the impact of groundwater and unstable sediments [218]. Therefore, we recommend scale-overlapping geoscientific approaches, including largeand medium-scale remote-sensing techniques, LiDAR modelling approaches [219-222] and noninvasive geophysical prospecting [223], as well as combined medium-, small- and micro-scale, minimally invasive direct push-sensing approaches, drilling campaigns and excavations [217,224-227]. 


\subsection{Advances in Multidisciplinary Big Data Sciences}

Digital humanities, remote-sensing and manifold database tools offer fundamentally new approaches to integrative floodplain research $[47,57,63,228-230]$. They enable the systematic integration of heterogeneous cultural and natural data such as texts, maps, place names, archaeological finds and geoscientific data [221,231-233], and allow for analyses of different spatial and chronological scales, from events to the longue durée [51,234-238]. The mandating of consistent standards for data quality, as well as homogeneous thematic thesauri, could enable the analysis of a range from local to supraregional floodplains as socio-natural sites beyond the limitations of specific disciplines and sources [239-242]. However, tapping the full potential of the digital humanities for a systematic modelling of human impacts on fluvial environments, as well as fluvial impacts on riverine societies, is essential.

\subsection{Progression of DNA Technology}

The rapid progression of DNA technology has brought about a quantum leap in approaches to research on modern and past biodiversity in rivers and wetlands. Regarding modern aquatic habitats, successful DNA technology applications in aquatic ecosystems include biotic screenings of environmental DNA on superficial river bottom samples. This enables, for example, the reconstruction of fish stock $[243,244]$ or the detection of invasive species. Regarding fluvial environments in the past, the emergence of studies of ancient DNA from aquatic sediments has opened up new possibilities for the reconstruction of past biotic inventories, because species that do not leave distinct morphological fossils, including microbiota, can also be determined $[245,246]$. Topics related to past aquatic environments include ecological reconstructions via plant metabarcoding [247], past fish population dynamics [248] and the spread and ecological effects of invasive species [249]. A methodological innovation is the use of DNA analysis in (geo)archaeological and historical contexts $[245,250,251]$. An established approach that holds promise for further development is the reconstruction of traded species provenances and trading networks through DNA analyses of ancient fish remains [252]. This approach can be applied to migratory fish remains [253], which might provide new insights into the dynamics of such species in the context of mill weir constructions and hunting during the preindustrial period.

\section{On the Way to the Fluvial Anthroposphere-Superimposed Emerging Fields}

Based on our review of the state-of-the-art, and the research limitations and perspectives we identified, we suggest six superimposed emerging fields to be further researched regarding the onset of the Fluvial Anthroposphere in Central Europe.

\subsection{Recovery and Understanding of Early Anthropogenic Forcing towards a Fluvial Anthroposphere}

Floodplains represent a global hotspot of sensitive socioenvironmental changes and early human forcing mechanisms with exceptional (geo)archaeological preservation conditions and high cross-disciplinary data availability and accessibility in archaeology, the geosciences and history. This might provide an opportunity to fundamentally improve the knowledge of socionatural relations in floodplains, and to reconstruct, understand and model the onset and transition from nature-dominated floodplains towards a Fluvial Anthroposphere, as well as their spatiotemporal variability.

\subsection{Studying and Understanding of Socionatural Sites within a Multidisciplinary Framework}

The material culture of past fluvial societies should be analysed and contrasted with historical, archaeological and geoscientific sources for the build-up of coevolutionary processes and models. Here, spatial quasi-fixed positions of floodplains as socio-natural sites encourage diachronic research strategies and the recovery of multicausal socionatural path dependencies. A multidisciplinary research approach provides a unique opportunity that combines the recent spatial and material turn of cultural studies with the cultural turn of the natural sciences. 


\subsection{Chronological Focus on the Medieval and Preindustrial Modern Periods}

The significant premodern transitions and developments of fluvio-cultural units towards the onset of the Fluvial Anthroposphere were probably fixed during the medieval period. Although the temporal research focus should, therefore, be on the medieval and preindustrial modern periods, the entirety of Holocene floodplain dynamics should be considered to quantify natural boundary levels, as well as onsets and peaks in anthropogenic forcing.

\subsection{Focus on Comparative and Diachronic Floodplain Studies}

Multidisciplinary studies should focus on the short-term (events) and long-term socionatural processes and feedbacks that take place in floodplains themselves, including second- and third-order floodplains in tributary subsystems. Due to the spatial and temporal asynchronies of past and contemporary socioenvironmental dynamics in floodplains, human forcing and the resulting feedback mechanisms should be investigated in comparative and diachronic studies.

\subsection{Quantifying and Modelling of Natural and Anthropogenic Processes}

Increasing human impact can be recovered within the diversity of socio-natural sites through artificial changes in the magnitudes and frequencies of geomorphological, hydrological and ecological processes, through direct anthropogenic modifications of 'natural' floodplain structures and developments of and changes in specific fluvial societies, as well as the feedback mechanisms occurring in socioecological models. Archaeologists, historians and geoscientists should jointly develop targeted research strategies and methodological concepts to build up quantitative and semiquantitative parameters and models of gradual transitions, abrupt tipping points and socioecological interactions. The aimed-for recovery and identification of natural boundary levels from floodplain archives under the consideration of multi-centennial 'Rapid Climate Changes' provide a high potential to distinguish between hydro-climatic and anthropogenic forcing mechanisms in floodplain genesis.

\subsection{Socioecological Risk Assessments}

These newly generated quantitative and semiquantitative parameters and models will support socioecological risk assessments, in accordance with the recovery of 'great transitions' towards a human-dominated Anthroposphere and in relation to the current Anthropocene debate and Global Change.

\section{Conclusions: Specific Thematic Objectives for Future Research}

Recalling the 10 specific thematic fields (Section 2), we recommend 10 specific thematic objectives to be considered in future research on the onset of the Fluvial Anthroposphere:

The first objective to consider is the recovery and modelling of social response mechanisms to abrupt events in floodplains. We particularly recommend systematic research that identifies and makes use of palaeohydrological and sociocultural key control variables. These will increase fundamental knowledge of the perception of and social responses to abrupt floodplain ecosystem changes due to extreme flood events, ice drift and droughts (e.g., artificial channel capturing, flood protection, societal adaptations).

The second objective to consider is the recovery and modelling of long-term social responses towards medium- and long-term changes in flood regimes and floodplain accessibility. We recommend research that will deepen the understanding of social adaption and wetland colonisation strategies with regard to hydro-climatic variations and attendant changes in flood regimes and floodplain ecosystems, as well as probable emergences of or declines in diseases such as malaria.

The third objective we recommend is the reconstruction and modelling of floodplain land use and potential modification of riparian vegetation by new multiproxy approaches. This will expand the breadth of research strategies beyond the common approaches: palynological records should be combined with dendrochronological data from buried riparian 
trees, fluvio-geomorphological data, geochemical proxy data and biomarkers and aDNA. This will produce a fuller understanding of overlapping and asynchronous patterns of climatic forcing, flood dynamics, riparian vegetation changes and direct human impact on floodplains.

The fourth objective to consider is the reconstruction and modelling of the effects of fishing, hunting, hydroengineering and floodplain habitat destruction on faunal biodiversity. We recommend research that diachronically synthesises chemical analytics, aDNA, (geo)archaeological data and written sources for the reconstruction of changes in migratory fish communities and faunal biodiversity.

The fifth objective we recommend is a cross-period synthesis of the history of hydroenergy exploitation and related socio-natural sites. We recommend a range from local to supraregional research approaches in order to synthesise the complex interplay between hydro-energy exploitation, floodplain morphology, socioeconomic transitions and path dependencies such as the long-term impacts of medieval mill weirs, hydro-sedimentary connectivity, floodplain ecosystems and floodplain colonisation.

The sixth objective to consider is the reconstruction and modelling of the impacts of craft, manufacturing and mining on floodplain dynamics and pollution. Innovative analytical approaches might enable a geochemical sink-to-source reconstruction of preindustrial contaminators. Furthermore, we recommend future research that couples geoscientific big datasets with archaeological and historical inventories.

The seventh objective to consider is the recovery of the socioecological and environmental significance of river crossings (bridges, fords, ferries). We recommend multidisciplinary research strategies that recover the diachronic history and path dependencies of river crossings and corresponding socionatural processes with regard to floodplain environments, material flows and land-use practices.

The eighth objective we recommend is a cross-period synthesis of the history of land reclamation and related socionatural floodplain sites. We recommend multidisciplinary research approaches that focus on the recovery of the history, involved agents, socionatural dynamics and the short- to long-term consequences of land reclamation in floodplains.

The ninth objective to consider consists of the cross-period synthesis of the history of channel engineering and inland navigation and related socio-natural floodplain sites. We recommend multidisciplinary and big data research strategies that recover the interplay between inland navigation, floodplain environments and socioeconomic strategies, as well as conflicts of interest.

The tenth objective to consider is the recovery of the interaction between legal rights and conflict management within the cross-period history of fluvio-cultural units. We recommend the use of systematic and comparative research concepts that investigate floodplain evolution and the involved fluvial societies in relation to Roman law, customary law and the formation of 'national' codifications.

\section{Outlook: The Establishment of New Avenues of Research and Potentials for Scientific Transfer}

Research into the onset of the Fluvial Anthroposphere will have a strong link to highly relevant topics of social significance. The Early Anthropocene/Anthropocene debate $[18,26,254]$ with a focus on fluvial landscapes $[36,121,255-259]$ is particularly notable, and the question of how to deal with natural resources and concomitant conflicts of use [7,9]. Furthermore, the response to river-related disasters, including subsequent strategies in environmental planning [260], could be improved.

In most temperate regions worldwide, the dominant models of natural lowland rivers are incised-meandering channels with flood loam deposition [261], which form the dominant template for floodplain restoration [7,262-264]. Hence, in most cases, these models are based on anthropogenic preconditions that are inappropriate for natural river systems. Nevertheless, this is an important factor in the context of riverine ecosystem services and floodplain rewilding based on European legal frameworks $[7,265]$. Future research on the onset of the Fluvial Anthroposphere will pave the way for a much more 
systematic exploration of emerging stages of the Fluvial Anthroposphere in Central Europe and, therefore, provide a tool for the better understanding of preanthropogenic, i.e., natural, floodplain stages.

Research on the onset of the Fluvial Anthroposphere in Central Europe will support the establishment of a floodplain archaeology and the 'Way to the Fluvial Anthroposphere', particularly as a general research topic and long-term field of research for heritage management. The current large-scale rewilding of rivers based on the European Water Framework Directive $[5,54]$ is not only a further major step forward in anthropogenic floodplain modification, but also a forms considerable threat to the fluvial cultural heritage, as it largely neglects archaeology.

Author Contributions: Conceptualization, L.W., G.J.S., N.M. and C.Z.; writing-original draft preparation, L.W., G.J.S., N.M. and C.Z.; writing-review and editing, L.W., N.M., G.J.S. and C.Z.; visualization, L.W., G.J.S., N.M. and C.Z.; project administration, L.W., G.J.S., N.M. and C.Z. All authors have read and agreed to the published version of the manuscript.

Funding: This research was funded by the German Research Foundation (DFG), grant numbers ME 3448/4-1, SCHE 678/6-1, WE 5445/2-1 and ZI 721/14-1.

Institutional Review Board Statement: Not applicable.

Informed Consent Statement: Not applicable.

Acknowledgments: We would like to thank the numerous participants of the DFG round-table meeting in Leipzig in 2019, which contributed significantly to this review. We would like to thank Gerardo Benito (Madrid), Antony Brown (Southampton), Paolo Mozzi (Padua), Petra van Dam (Amsterdam), Christian Rohr (Bern), Claus von Carnap-Bornheim (Schleswig) and Richard Jones (Leicester) for their very helpful and fundamental comments on a first draft of this review. Further, we would like to thank Johannes Rabiger-Völlmer for the data compilation and drawing of the Central European river catchments in Figure 1 of this review. Our sincere thanks go to Barbara Weiner, Helen Ballasus, Cathleen Kertscher and Daniel McNaughton for proofreading of the review. The review formed the basis for a framework proposal, which led to the successful establishment of the DFG Priority Programme ‘On the Way to the Fluvial Anthroposphere' (SPP 2361) in spring 2021.

Conflicts of Interest: The authors declare no conflict of interest. The funders had no role in the design of the study; in the collection, analyses, or interpretation of data; in the writing of the manuscript or in the decision to publish the results.

\section{References}

1. Goudie, A.S. Encyclopedia of Geomorphology, 1st ed.; Routledge: New York, NY, USA, 2004.

2. Hamilton, S.K. Flood Plains. In Encyclopedia of Inland Waters, 1st ed.; Likens, G.E., Ed.; Elsevier: Amsterdam, The Netherlands, 2009; pp. 378-386.

3. Council of Europe. European Convention on the Protection of the Archaeological Heritage. La Valletta, Malta, 1992. Available online: https: / / www.coe.int/en/web/conventions/full-list/ (accessed on 18 July 2019).

4. Knoll, M. Die Natur der Menschlichen Welt. Siedlung, Territorium und Umwelt in der Historisch-Topografischen Literatur der Frühen Neuzeit, 1st ed.; Transcript: Bielefeld, Germany, 2013.

5. Hein, C. Adaptive Strategies for Water Heritage: Past, Present and Future, 1st ed.; Springer: Cham, Germany, 2020.

6. Tockner, K.; Tonolla, D.; Uehlinger, U.; Siber, R.; Robinson, C.T.; Peter, F.D. Introduction to European Rivers. In Rivers of Europe, 1st ed.; Tockner, K., Zarfl, C., Robinson, C., Eds.; Elsevier: London, UK, 2009; pp. 1-21.

7. Brown, A.G.; Lespez, L.; Sear, D.A.; Macaire, J.J.; Houben, P.; Klimek, K.; Brazier, R.E.; Van Oost, K.; Pears, B. Natural vs anthropogenic streams in Europe: History, ecology and implications for restoration, river-rewilding and riverine ecosystem services. Earth-Sci. Rev. 2018, 180, 185-205. [CrossRef]

8. Hoffmann, T.; Thorndycraft, V.; Brown, A.G.; Coulthard, T.J.; Damnati, B.; Kale, V.; Middelkoop, H. Human impact on fluvial regimes and sediment flux during the Holocene: Review and future research agenda. Glob. Planet. Chang. 2010, 72, 87-98. [CrossRef]

9. Macklin, M.G.; Lewin, J. River stresses in anthropogenic times: Large-scale global patterns and extended environmental timelines. Prog. Phys. Geogr. 2019, 43, 3-23. [CrossRef]

10. Hoffmann, R.C. Elemental Resources and Aquatic Ecosystems: Medieval Europeans and their Rivers. In A History of Water: Rivers and Society. From Early Civilizations to Modern Times, 1st ed.; Tvedt, T., Coopey, R., Eds.; Tauris: London, UK, 2010; Volume 2, pp. 165-202. 
11. Macklin, M.G.; Lewin, J. The rivers of civilization. Quat. Sci. Rev. 2015, 114, 228-244. [CrossRef]

12. Verstraeten, G.; Broothaerts, N.; Van Loo, M.; Notebaert, B.; D’Haen, K.; Dusar, B.; De Brue, H. Variability in fluvial geomorphic response to anthropogenic disturbance. Geomorphology 2017, 294, 20-39. [CrossRef]

13. Waters, C.N.; Zalasiewicz, J.; Summerhayes, C.P.; Barnosky, A.D.; Poirier, C.; Gałuszka, A.; Cearreta, A.; Edgeworth, M.; Ellis, E.C.; Ellis, M.; et al. The Anthropocene is functionally and stratigraphically distinct from the Holocene. Science 2016, 351, aad2622. [CrossRef]

14. Quenet, G. L'Anthropocène et le temps des historiens. Ann. Hist. Sci. Soc. 2017, 72, 165-197. [CrossRef]

15. Lewis, S.L.; Maslin, M. The Human Planet. How We Created the Anthropocene, 1st ed.; Yale University Press: New Haven, CT, USA, 2018.

16. Mauelshagen, F. Die große Stoffwechselanomalie. Jahrb. Okon. Ges. 2019, 30, 17-46.

17. Zalasiewicz, J.; Waters, C.N.; Williams, M.; Summerhayes, C.P. (Eds.) The Anthropocene as a Geological Time Unit. A Guide to the Scientific Evidence and Current Debate, 1st ed.; Cambridge University Press: Cambridge, UK, 2019.

18. Ellis, E.C. Anthropocene: A Very Short Introduction, 1st ed.; Oxford University Press: New York, NY, USA, 2018.

19. Gleeson, T.; Wang-Erlandsson, L.; Zipper, S.C.; Porkka, M.; Jaramillo, F.; Gerten, D.; Fetzer, I.; Cornell, S.E.; Piemontese, L.; Gordon, L.J.; et al. The water planetary boundary. Interrogation and revision. One Earth 2020, 2, 223-234. [CrossRef]

20. He, F.; Zarfl, C.; Bremerich, V.; David, J.N.W.; Hogan, Z.; Kalinkat, G.; Tockner, K.; Jähnig, S.C. The global decline of freshwater megafauna. Glob. Chang. Biol. 2019, 25, 3883-3892. [CrossRef]

21. Meybeck, M. Global analysis of river systems: From Earth system controls to Anthropocene syndromes. Philos. Trans. R. Soc. B 2003, 358, 1935-1955. [CrossRef] [PubMed]

22. Messerli, B.; Grosjean, M.; Hofer, T.; Núñez, L.; Pfister, C. From nature-dominated to human-dominated environmental changes. Quat. Sci. Rev. 2000, 19, 459-479. [CrossRef]

23. van Dam, P. An Amphibious Culture: Coping with Floods in the Netherlands. In Local Places, Global Processes. Histories of Environmental Change in Britain and Beyond, 1st ed.; Coates, P., Moon, D., Warde, P., Eds.; Oxbow Books: Oxford, UK, 2016; pp. 78-93.

24. Gerten, D.; Hoff, H.; Rockström, J.; Jägermeyr, J.; Kummu, M.; Pastor, A.V. Towards a revised planetary boundary for consumptive freshwater use: Role of environmental flow requirements. Curr. Opin. Environ. Sustain. 2013, 5, 551-558. [CrossRef]

25. Winiwarter, V.; Schmid, M.; Dressel, G. Looking at half a millennium of co-existence. The Danube in Vienna as a socio-natural site. Water Hist. 2013, 5, 101-119. [CrossRef]

26. Tarolli, P.; Cao, W.; Sofia, G.; Evans, D.; Ellis, E. From features to fingerprints: A general diagnostic framework for Anthropogenic geomorphology. Prog. Phys. Geogr. 2019, 43, 95-128. [CrossRef]

27. Benito, G.; Macklin, M.G.; Panin, A.; Rossato, S.; Fontana, A.; Jones, A.F.; Machado, M.J.; Matlakhova, E.; Mozzi, P.; Zielhofer, C. Recurring flood distribution patterns related to short-term Holocene climatic variability. Sci. Rep. 2015, 5, 16398. [CrossRef] [PubMed]

28. Macklin, M.G.; Benito, G.; Gregory, K.J.; Johnstone, E.; Lewin, J.; Michczyńska, D.J.; Soja, R.; Starkel, L.; Thorndycraft, V.R. Past hydrological events reflected in the Holocene fluvial record of Europe. Catena 2006, 66, 145-154. [CrossRef]

29. Zolitschka, B.; Behre, K.E.; Schneider, J. Human and climatic impact on the environment as derived from colluvial, fluvial and lacustrine archives—examples from the Bronze Age to the Migration period, Germany. Quat. Sci. Rev. 2003, 22, 81-100. [CrossRef]

30. Houben, P.; Hoffmann, T.; Zimmermann, A.; Dikau, R. Land use and climatic impacts on the Rhine system (RheinLUCIFS): Quantifying sediment fluxes and human impact with available data. Catena 2006, 66, 42-52. [CrossRef]

31. Hoffmann, T.; Lang, A.; Dikau, R. Holocene river activity: Analysing 14C-dated fluvial and colluvial sediments from Germany. Quat. Sci. Rev. 2008, 27, 2031-2040. [CrossRef]

32. Völkel., J. (Ed.) Colluvial sediments, flood loams and peat bogs. In Zeitschrift für Geomorphologie; Schweizerbart: Stuttgart, Germany, 2005; Volume 139.

33. Abrantes, F.; Lebreiro, S.; Rodrigues, T.; Gil, I.; Bartels-Jónsdóttir, H.; Oliveira, P.; Kissel, C.; Grimalt, J.O. Shallow-marine sediment cores record climate variability and earthquake activity off Lisbon (Portugal) for the last 2000 years. Quat. Sci. Rev. 2005, 24, 2477-2494. [CrossRef]

34. Hepp, D.A.; Romero, O.E.; Mörz, T.; Pol-Holz, R.; de, Hebbeln, D. How a river submerges into the sea: A geological record of changing a fluvial to a marine paleoenvironment during early Holocene sea level rise. J. Quat. Sci. 2019, 34, 581-592. [CrossRef]

35. Hoffmann, T.; Erkens, G.; Gerlach, R.; Klostermann, J.; Lang, A. Trends and controls of Holocene floodplain sedimentation in the Rhine catchment. Catena 2009, 77, 96-106. [CrossRef]

36. Brown, A.G.; Toms, P.; Carey, C.; Rhodes, E. Geomorphology of the Anthropocene: Time-trangressive discontinuities of humaninduced alluviation. Anthropocene 2013, 1, 3-13. [CrossRef]

37. Collins, A.L.; Walling, D.E. Fine-grained bed sediment storage within the main channel systems of the Frome and Piddle catchments, Dorset, UK. Hydrol. Process. 2007, 21, 1449-1459. [CrossRef]

38. Notebaert, B.; Broothaerts, N.; Verstraeten, G. Evidence of anthropogenic tipping points in fluvial dynamics in Europe. Glob. Planet. Change 2018, 164, 27-38. [CrossRef]

39. Dotterweich, M. The history of soil erosion and fluvial deposits in small catchments of central Europe: A review. Geomorphology 2008, 101, 192-208. [CrossRef] 
40. Broothaerts, N.; Notebaert, B.; Verstraeten, G.; Kasse, C.; Bohncke, S.; Vandenberghe, J. Non-uniform and diachronous Holocene floodplain evolution. A case study from the Dijle catchment, Belgium. J. Quat. Sci. 2014, 29, 351-360. [CrossRef]

41. Fuchs, M.; Will, M.; Kunert, E.; Kreutzer, S.; Fischer, M.; Reverman, R. The temporal and spatial quantification of Holocene sediment dynamics in a meso-scale catchment in northern Bavaria, Germany. Holocene 2011, 21, 1093-1104. [CrossRef]

42. Gerlach, R. Flußdynamik des Mains unter dem Einfluß des Menschen seit dem Spätmittelalter, 1st ed.; Zentralausschuß für Deutsche Landeskunde: Trier, Germany, 1990.

43. Houben, P.; Schmidt, M.; Mauz, B.; Stobbe, A.; Lang, A. Asynchronous Holocene colluvial and alluvial aggradation: A matter of hydrosedimentary connectivity. Holocene 2013, 23, 544-555. [CrossRef]

44. Zielhofer, C.; Leitholdt, E.; Werther, L.; Stele, A.; Bussmann, J.; Linzen, S.; Schneider, M.; Meyer, C.; Berg-Hobohm, S.; Ettel, P. Charlemagne's Summit Canal: An early medieval hydro-engineering project for passing the Central European watershed. PLoS ONE 2014, 9, e108194. [CrossRef]

45. Werther, L.; Kröger, L.; Kirchner, A.; Zielhofer, C.; Leitholdt, E.; Schneider, M.; Linzen, S.; Berg-Hobohm, S.; Ettel, P. Fossata Magna-A Canal Contribution to Harbour Construction in the 1st Millennium AD; RGZM Tagungen; RGZM: Mainz, Germany, 2018; Volume 34, pp. 355-372.

46. Vayssière, A.; Castanet, C.; Gautier, E.; Virmoux, C.; Dépret, T.; Gandouin, E.; Develle, A.L.; Mokadem, F.; Saulnier-Copard, S.; Sabatiere, P.; et al. Readjustments of a sinuous river during the last 6000 years in northwestern Europe (Cher River, France): From an active meandering river to a stable river course under human forcing. Geomorphology 2020, 370, 107395. [CrossRef]

47. Jones, R.; Gregory, R.; Kilby, S.; Pears, B. Living with a trespasser: Riparian names and medieval settlement on the River Trent floodplain. PCA 2017, 7, 33-64.

48. Walter, R.C.; Merritts, D.J. Natural streams and the legacy of water-powered mills. Science 2008, 319, 299-304. [CrossRef]

49. Beauchamp, A.; Lespez, L.; Delahaye, D. Impact des aménagements hydrauliques sur les systèmes fluviaux bas-normand depuis 2000 ans. Quaternaire 2017, 28, 253-258. [CrossRef]

50. Petts, G.E.; Möller, H.; Roux, A.L. (Eds.) Historical Changes of Large Alluvial Rivers: Western Europe, 1st ed.; John Wiley: Chichester, UK, 1989.

51. Hohensinner, S.; Sonnlechner, C.; Schmid, M.; Winiwarter, V. Two steps back, one step forward: Reconstructing the dynamic Danube riverscape under human influence in Vienna. Water Hist. 2013, 5, 121-143. [CrossRef]

52. Longoni, R.; Wetter, O. Urban stream works in Central Europe 1200-1700. Municipal administration, hydraulic engineering and flood reconstruction. Water Hist. 2019, 11, 31-57. [CrossRef]

53. Peng, F.; Prins, M.A.; Kasse, C.; Cohen, K.M.; Van der Putten, N.; van der Lubbe, J.; Toonen, W.H.J.; van Balen, R.T. An improved method for paleoflood reconstruction and flooding phase identification, applied to the Meuse River in the Netherlands. Glob. Planet. Chang. 2019, 177, 213-224. [CrossRef]

54. von Carnap-Bornheim, C.; Knieps, E. Denkmalschutz und die Umsetzung der Wasserrahmenrichtlinie. Mitt. DGAMN 2009, 21, 9-16.

55. Bork, H.R.; Brose, F.; Herking, C.; Heussner, K.-U.; Jahns, S. Das Wechselverhältnis zwischen der menschlichen Tätigkeit und den naturräumlichen Verhältnissen. In Forschungen zu Mensch und Umwelt im Odergebiet in ur- und Frühgeschichtlicher Zeit, 1st ed.; Gringmuth-Dallmer, E., Leciejewicz, L., Eds.; Phillip von Zabern: Mainz, Germany, 2003; pp. 373-391.

56. Gringmuth-Dallmer, E.; Leciejewicz, L. Forschungen zu Mensch und Umwelt im Odergebiet in ur- und Frühgeschichtlicher Zeit, 1st ed.; Phillip von Zabern: Mainz, Germany, 2002.

57. van Dinter, M.; Cohen, K.M.; Hoek, W.Z.; Stouthamer, E.; Jansma, E.; Middelkoop, H. Late Holocene lowland fluvial archives and geoarchaeology: Utrecht's case study of Rhine river abandonment under Roman and Medieval settlement. Quat. Sci. Rev. 2017, 166, 227-265. [CrossRef]

58. Jansma, E.; van Lanen, R.J.; Pierik, H.J. Travelling through a river delta: A landscape-archaeological reconstruction of river development and long-distance connections in the Netherlands during the first millennium AD. Mediev. Settl. Res. 2017, 32, 35-39.

59. Poláček, L. River Archaeology and the Search for a Harbour in Mikulčice; RGZM Tagungen; RGZM: Mainz, Germany, 2019; Volume 38, pp. 179-190.

60. Plumettaz, N.; Pillonel, D.; Thew, N. Aménagements Fluviaux de La Thielle au Moyen Âge Pêcherie et Moulin de Pré de la Mottaz. Office et musée cantonal d'archéologie de Neuchâtel: Hautrive, Switzerland, 2011; Volume 48.

61. Monteil, M.; Arthuis, R. Archéologie de la Basse-Loire, 1st ed.; PU Rennes: Rennes, France, 2015.

62. Berthold, J. Das Elsbachtal im Mittelalter und Früher Neuzeit; Archäologie einer Kulturlandschaft; Rheinische Ausgrabungen; Philipp von Zabern: Bonn, Germany, 2016; Volume 74.

63. Foucher, M.; Dumont, A.; Werther, L.; Wollenberg, D. Inland Harbours in Central Europe: Nodes between Northern Europe and the Mediterranean Sea; RGZM Tagungen; Schnell \& Steiner: Mainz, Germany, 2019; Volume 38.

64. Rippon, S. The Transformation of Coastal Wetlands. Exploitation and Management of Marshland Landscapes in North West Europe during the Roman and Medieval Periods, 1st ed.; Oxford University Press: Oxford, UK, 2000.

65. Campbell, J.B. Rivers and the Power of Ancient Rome, 1st ed.; University of North Carolina Press: Chapel Hill, NC, USA, 2012.

66. O'Sullivan, A. Europe's Wetlands from the Migration Period to the Middle Ages. Settlement, Exploitation and Transformation, AD 400-1500. In The Oxford Handbook of Wetland Archaeology, 1st ed.; Menotti, F., O'Sullivan, A., Eds.; Oxford University Press: Oxford, UK, 2013; pp. 27-53. 
67. Diener, A.; Untermann, M. Wasserbau in Mittelalter und Neuzeit; Mitt. DGAMN: Paderborn, Germany, 2009.

68. Dumont, A. Archéologie fluviale en Europe; Dossiers d'archéologie: Dijon, France, 2009.

69. Conijn, A.; Lange, J.; Zube, C.; Mächtle, B.; Meier, T. Early Floods and Early Dikes: Research Strategy in Combing Geoarchaeological and Historical Sources in the Upper Rhine Valley; RGZM Tagungen; Schnell \& Steiner: Mainz, Germany, 2019; Volume 38, pp. $245-263$.

70. Maavara, T.; Chen, Q.; van Meter, K.; Brown, L.E.; Zhang, J.; Ni, J.; Zarfl, C. River dam impacts on biogeochemical cycling. Nat. Rev. Earth Environ. 2020, 1, 103-116. [CrossRef]

71. Demangeon, A.; Febvre, L. Le Rhin_Problèmes d'Histoire et d'Economie, 1st ed.; Colin: Paris, France, 1935.

72. Rossiaud, J. Le Rhône au Moyen Âge: Histoire et Représentation d'un Fleuve Européen, 1st ed.; Aubier: Paris, France, 2007.

73. Leguay, J. L'eau Dans la Ville au Moyen Age, 1st ed.; PU Rennes: Rennes, France, 2002.

74. Scheutz, M.; Weigl, H. Verwaltetes Wasser im Österreich des Spätmittelalters und der Frühen Neuzeit; Forschungen zur Landeskunde von Niederösterreich; Verein f. Landeskde v. Niederösterr: St. Pölten, Austria, 2015; Volume 37.

75. Knoll, M.; Lübken, U.; Schott, D. Rivers Lost, Rivers Regained. Rethinking City-River Relations, 1st ed.; University of Pittsburgh Press: Pittsburgh, PA, USA, 2017.

76. Tvedt, T.; Jakobsson, E. A History of Water: Water Control and River Biographies, 1st ed.; Tauris: London, UK, 2006 ; Volume 1.

77. Tvedt, T.; Coopey, R. A History of Water: Rivers and Society. From Early Civilizations to Modern Times, 1st ed.; Tauris: London, UK, 2010; Volume 2.

78. Schmid, M.; Haidvogl, G. Coupling the long-term dynamics of natural and social systems: Towards an environmental history of the Danube. In Human Nature: Studies in History Ecology and Environmental History, 1st ed.; Szabó, P., Hédl, R., Eds.; Institute of Botany of the Academy of Sciences: Brno, Czech Republic, 2008; pp. 64-73.

79. Blair, J. Waterways and Canal-Building in Medieval England, 1st ed.; Oxford University Press: Oxford, UK, 2007.

80. Bütow, S. Straßen im Fluss. Schifffahrt, Flussnutzung und der Lange Wandel der Verkehrsinfrastruktur in der Mark Brandenburg und der Niederlausitz vom 13. bis zum 16. Jahrhundert, 1st ed.; Lukas: Berlin, Germany, 2015.

81. Schenk, G.J. Knoten' in ,Netzen'? Überlegungen zur Hafenstadt als kritische Infrastruktur; RGZM Tagungen; Schnell \& Steiner: Mainz, Germany, 2019; Volume 39, pp. 207-236.

82. Cioc, M. The Rhine. An Eco-Biography, 1st ed.; Combined Academic Publ.: Seattle, WA, USA, 2002.

83. Vadas, A. Long-Term perspectives on river floods. The Dominican Nunnery on Margaret Island (Budapest) and the Danube River. Interdiscip. Archaeol. 2013, 4, 73-82. [CrossRef]

84. Schenk, G.J. Managing Natural Hazards: Environment, Society, and Politics in Tuscany and the Upper Rhine Valley in the Renaissance (1270-1570). In Historical Disasters in Context: Science, Religion, and Politics (Routledge Studies in Cultural History 15), 1st ed.; Janku, A., Schenk, G.J., Mauelshagen, F., Eds.; Taylor \& Francis: New York, NY, USA, 2012; pp. 31-53.

85. Labbé, T. Les Catastrophes Naturelles au Moyen Âge, XIIe-XVe Siècle, 1st ed.; CNRS Editions: Paris, France, 2017.

86. Kiss, A. Floods and Long-Term Water-Level Changes in Medieval Hungary, 1st ed.; Springer: Cham, Germany, 2019.

87. Squatriti, P. Working with Water in Medieval Europe. Technology and Resource-Use (Technology and Change in History 3), 1st ed.; Brill Academic: Leiden, The Netherlands, 2000.

88. Rohr, C. Floods of the upper Danube River and its tributaries and their impact on urban economies (c. 1350-1600): The examples of the towns of Krems/Stein and Wels (Austria). Environ. Hist. 2013, 19, 133-148. [CrossRef]

89. Campopiano, M.; Curtis, D. Medieval land reclamation and the creation of new societies: Comparing Holland and the Po Valley, c. 800-c.1500. J. Hist. Geogr. 2013, 44, 93-108.

90. Schenk, G.J. Das Baby in der Wiege. Hochwasser zwischen Alltag und Katastrophe (ca. 1250-1550). Beobachtungen zur ,fluvialen Anthroposphäre' im Kraichgau. In Wasser. Ressource_Gefahr_Leben (Kraichtaler Kolloquien 12), 1st ed.; Andermann, K., Schenk, G.J., Eds.; Thorbecke: Ostfildern, Germany, 2020; pp. 79-113.

91. Galloway, J.A. Storm flooding, coastal defense and land use around the Thames estuary and tidal river c. 1250-1450. J. Mediev. Hist. 2009, 35, 171-188. [CrossRef]

92. Ciriacono, S. Building on Water: Venice, Holland and the Construction of the European Landscape in Early Modern Times, 1st ed.; Berghahn: New York, NY, USA, 2006.

93. Rückert, P. Hochwasser und Flussbau: Zur anthropogenen Gestaltung der Flusslandschaft am Oberrhein im späteren Mittelalter. Siedlungsforschung 2005, 23, 113-129.

94. Haidvogl, G.; Hoffmann, R.; Pont, D.; Jungwirth, M.; Winiwarter, V. Historical ecology of riverine fish in Europe. Aquat. Sci. 2015, 77, 315-324. [CrossRef]

95. Schenk, G.J. Lorsch und das Wasser. In Laureshamensia. Forschungsberichte des Experimentalarchäologischen Freilichtlabors Karolingischer Herrenhof Lauresham; Verwaltung der Staatlichen Schlösser und Gärten: Homburg v. d. Höhe, Germany, 2021; Volume 3, pp. 32-51.

96. Hoffmann, R.C. An Environmental History of Medieval Europe, 1st ed.; Cambridge University Press: Cambridge, UK, 2014.

97. Bauch, M.; Schenk, G.J. Teleconnections, Correlations, Causalities between Nature and Society? In The Crisis of the 14th Century: Teleconnections between Environmental and Societal Change? (Das Mittelalter. Perspektiven Mediävistischer Forschung. Beihefte 13), 1st ed.; Bauch, M., Schenk, G., Eds.; de Gruyter: Berlin, Germany, 2020; pp. 1-22.

98. Fischer-Kowalski, M.; Weisz, H. Society as hybrid between material and symbolic realms: Toward a theoretical framework of society-nature interaction. Adv. Hum. Ecol. 1999, 8, 215-254. 
99. Schenk, G.J. Historical Disaster Experiences. First Steps toward a Comparative and Transcultural History of Disasters across Asia and Europe in the Preindustrial Era. In Historical Disaster Experiences, 1st ed.; Schenk, G.J., Ed.; Springer: Cham, Germany, 2017; pp. 3-44.

100. Barry, A.; Born, G. Interdisciplinarity: Reconfigurations of the Social and Natural Sciences, 1st ed.; Taylor \& Francis: New York, NY, USA, 2013

101. Izdebski, A.; Pickett, J.; Roberts, N.; Waliszewski, T.B. The environmental, archaeological and historical evidence for regional climatic changes and their societal impacts in the Eastern Mediterranean in Late Antiquity. Quat. Sci. Rev. 2016, 136, 189-208. [CrossRef]

102. Haldon, J.; Mordechai, L.; Newfield, T.P.; Chase, A.F.; Izdebski, A.; Guzowski, P.; Labuhn, I.; Roberts, N. History meets palaeoscience: Consilience and collaboration in studying past societal responses to environmental change. Proc. Natl. Acad. Sci. USA 2018, 115, 3210-3218. [CrossRef] [PubMed]

103. Wittfogel, K. Oriental Despotism. A Comparative Study of Total Power, 1st ed.; Yale University Press: New Haven, CT, USA, 1957.

104. Holenstein, A. Empowering Interactions: Looking at Statebuilding from Below. In Empowering Interactions, Political Cultures and the Emergence of the State in Europe 1300-1900, 1st ed.; Blockmans, W., Schlappi, D., Eds.; Taylor \& Francis: Farnham, VA, USA, 2009; pp. 1-31.

105. Edgeworth, M. Rivers as Material Infrastructure: A Legacy from the Past to the Future. In Water and Power in Past Societies, 1st ed.; Holt, E., Ed.; SUNY Press: Albany, NY, USA, 2018; pp. 243-257.

106. Schulte, L.; Schillereff, D.; Santisteban, J. Pluridisciplinary analysis and multi-archive reconstruction of paleofloods: Societal demand, challenges and progress. Glob. Planet. Chang. 2019, 177, 225-238. [CrossRef]

107. Foulds, S.A.; Brewer, P.A.; Macklin, M.G.; Haresign, W.; Betson, R.E.; Rassner, S.M.E. Flood-related contamination in catchments affected by historical metal mining: An unexpected and emerging hazard of climate change. Sci. Total Environ. 2014, 476/477, 165-180. [CrossRef] [PubMed]

108. Ellis, E.C.; Kaplan, J.O.; Fuller, D.Q.; Vavrus, S.; Goldewijk, K.K.; Verburg, P.H. Used planet: A global history. Proc. Natl. Acad. Sci. USA 2013, 110, 7978-7985. [CrossRef]

109. Syvitski, J.P.M.; Vörösmarty, C.J.; Kettner, A.J.; Green, P. Impact of humans on the flux of terrestrial sediment to the global coastal ocean. Science 2005, 308, 376-380. [CrossRef]

110. Pears, B.; Brown, A.G.; Toms, P.S.; Wood, J.; Sanderson, D.; Jones, R. A sub-centennial-scale optically stimulated luminescence chronostratigraphy and late Holocene flood history from a temperate river confluence. Geology 2020, 48, 819-825. [CrossRef]

111. Rockström, J.; Steffen, W.; Noone, K.; Persson, A.; Chapin, F.S., III; Lambin, E.F.; Lenton, T.M.; Scheffer, M.; Folke, C.; Schellnhuber, H.J.; et al. Planetary boundaries: Exploring the safe operating space for humanity. Ecol. Soc. 2009, 14, 32. [CrossRef]

112. Gerrard, C.; Petley, D.N. A risk society? Environmental hazards, risk and resilience in the Later Middle Ages in Europe. Nat. Hazards 2013, 69, 1051-1079. [CrossRef]

113. Steffen, W.; Richardson, K.; Rockström, J.; Cornell, S.E.; Fetzer, I.; Bennett, E.M.; Biggs, R.; Carpenter, S.R.; de Vries, W.; de Wit, C.A.; et al. Planetary boundaries: Guiding human development on a changing planet. Science 2015, 347, 1259855. [CrossRef] [PubMed]

114. Verstraeten, G.; Lang, A.; Houben, P. Human impact on sediment dynamics—quantification and timing. Catena 2009, 77, 77-80. [CrossRef]

115. Bond, G.; Kromer, B.; Beer, J.; Muscheler, R.; Evans, N.E.; Showers, W.; Hoffmann, S.; Lotti-Bond, R.; Hajdas, I.; Bonani, G. Persistent solar influence on North Atlantic climate during the Holocene. Science 2001, 294, 2130-2136. [CrossRef]

116. Mayewski, P.A.; Rohling, E.C.; Stager, J.C.; Karlén, W.; Maasch, K.A.; Meeker, L.D.; Meyerson, E.A.; Gasse, F.; van Kreveld, S.; Holmgren, K.; et al. Holocene climate variability. Quat. Res. 2004, 62, 243-255. [CrossRef]

117. Steinhilber, F.; Beer, J.; Fröhlich, C. Total solar irradiance during the Holocene. Geophys. Res. Lett. 2009, 36, L19704. [CrossRef]

118. Zielhofer, C.; Köhler, A.; Mischke, S.; Benkaddour, A.; Mikdad, A.; Fletcher, W.J. Western Mediterranean hydro-climatic consequences of Holocene ice-rafted debris (Bond) events. Clim. Past 2019, 15, 463-475. [CrossRef]

119. Magny, M. Holocene climate variability as reflected by mid-European lake-level fluctuations and its probable impact on prehistoric human settlements. Quat. Int. 2004, 113, 65-79. [CrossRef]

120. Benito, G.; Sopena, A.; Sanchez-Moya, Y.; Machado, M.J.; Pérez-González, A. Palaeoflood record of the Tagus River (Central Spain) during the Late Pleistocene and Holocene. Quat. Sci. Rev. 2003, 22, 1737-1756. [CrossRef]

121. Faust, D.; Zielhofer, C.; Baena, R.; Diaz del Olmo, F. High resolution fluvial record of late Holocene geomorphic changes in Tunisia: Climatic or human impact? Quat. Sci. Rev. 2004, 23, 1757-1775. [CrossRef]

122. Herget, J.; Kapala, A.; Krell, M.; Rustemeier, E.; Simmer, C.; Wyss, A. The millennium flood of July 1342 revisited. Catena 2015, 130, 82-94. [CrossRef]

123. Dreibrodt, S.; Lubos, C.; Terhorst, B.; Damm, B.; Bork, H.R. Historical soil erosion by water in Germany: Scales and archives. Quat. Int. 2010, 222, 80-95. [CrossRef]

124. Kiss, A.; Nikolic, Z. Droughts, dry spells and low water levels in medieval Hungary (and Croatia) I: The great droughts of 1362, 1474, 1479, 1494 and 1507. J. Environ. Geogr. 2015, 8, 11-22. [CrossRef]

125. Schenk, W.; Dix, A. Naturkatastrophen und Naturrisiken in der Vorindustriellen Zeit und ihre Auswirkungen auf Siedlungen und Kulturlandschaft (Siedlungsforschung 23), 1st ed.; Arkum: Bonn, Germany, 2005. 
126. Rohr, C. Extreme Naturereignisse im Ostalpenraum. Naturerfahrung im Spätmittelalter und am Beginn der Neuzeit (Umwelthistorische Forschungen 4), 1st ed.; Böhlau: Köln, Germany, 2007.

127. Brazdil, R.; Kundzewicz, Z.; Benito, G. Historical hydrology for studying flood risk in Europe. Hydrol. Sci. J. 2006, 51, 739-764. [CrossRef]

128. Fouquet, G.; Zeilinger, G. Katastrophen im Spätmittelalter, 1st ed.; Philipp von Zabern: Darmstadt, Germany, 2011.

129. Wetter, O.; Pfister, C.; Weingartner, R.; Luterbacher, J.; Reist, T.; Trösch, J. The largest floods in the High Rhine basin since 1268 assessed from documentary and instrumental evidence. Hydrol. Sci. J. 2011, 56, 733-758. [CrossRef]

130. Himmelsbach, I.; Glaser, R.; Schoenbein, D.; Rieman, D.; Martin, B. Reconstruction of flood events based on documentary data and transnational flood risk analysis of the Upper Rhine and its French and German tributaries since AD 1480. Hydrol. Earth Syst. Sci. 2015, 19, 4149-4164. [CrossRef]

131. Deutsch, M.; Pörtge, K.-H. Hochwasser in Thüringen. Ursachen, Verlauf und Schäden Extremer Abflussereignisse (1500-2015), 1st ed.; Thüringer Landesanstalt für Umwelt und Geologie: Jena, Germany, 2017.

132. Pfister, C. Learnng from Nature-Induced Disasters: Theoretical Considerations and Case studies from Western Europe. In Natural Disasters, Cultural Responses: Case Studies toward a Global Environmental History, 1st ed.; Mauch, C., Pfister, C., Eds.; Lexington: Lanham, MD, USA, 2009; pp. 17-40.

133. Botter, G.; Basso, S.; Rodriguez-Iturbe, I.; Rinaldo, A. Resilience of river flow regimes. Proc. Natl. Acad. Sci. USA 2013, 110, 12925-12930. [CrossRef]

134. Bauch, M. St. Mary Magdelene's Flood (1342) at the intersection of environmental history and the history of infrastructures. NTM Z. Gesch. Wiss. Tech. Med. 2019, 27, 273-309.

135. Glaser, R. Klimageschichte Mitteleuropas. 1200 Jahre Wetter, Klima, Katastrophen, 3rd ed.; wbg Academic: Darmstadt, Germany, 2013.

136. De Souza, J.G.; Robinson, M.; Maezumi, S.Y.; Capriles, J.; Hoggarth, J.A.; Lombardo, U.; Novello, V.F.; Apaéstegui, J.; Whitney, B.; Urrego, D.; et al. Climate change and cultural resilience in late pre-Columbian Amazonia. Nat. Ecol. Evol. 2019, 3, 1007-1017. [CrossRef]

137. Pears, B.; Brown, A.G.; Carroll, J.; Toms, P.S.; Wood, J.C.; Jones, R. Early medieval place-names and riverine flood histories. A new approach and new chronostratigraphic records for three English rivers. Eur. J. Archaeol. 2020, 20, 1-25. [CrossRef]

138. Zschieschang, C. Ortsnamen und Gewässer-Eine komplexe Beziehung. Onomast. Investig. 2020, 2, $327-341$.

139. Zschieschang, C.; Maříková, M. (Eds.) Wassermühlen und Wassernutzung im Mittelalterlichen Ostmitteleuropa, 1st ed.; Steiner: Stuttgart, Germany, 2015.

140. Smith-Guzmán, N.E. Cribra orbitalia in the ancient Nile Valley and its connection to malaria. Int. J. Paleopathol. 2015, 10, 1-12. [CrossRef] [PubMed]

141. Newfield, T.P. Malaria and malaria-like disease in the early Middle Ages. Early Mediev. Eur. 2017, 25, 251-300. [CrossRef]

142. Kaiser, K.; Lorenz, S.; Germer, S.; Joschus, O.; Küster, M.; Libra, J.; Bens, O.; Hüttl, R. Late Quaternary evolution of rivers, lakes and peatlands in northeast Germany reflecting past climatic and human impact-An overview. EEG Quat. Sci. J. 2012, 61, 103-132.

143. Mayr, C.; Matzke-Karasz, R.; Manthe, P.; Arnold, J.; Hänfling, C.; Hilber, J.; Spitzenberger, D.; Schmid, W.; Schönfeld, G. Environmental change in the vicinity of the Neolithic wetland settlement Pestenacker (S-Germany) during the last 6600 years. J. Archaeol. Sci. 2015, 54, 396-409. [CrossRef]

144. Lechner, A. Palaeohydrologic conditions and geomorphic processes during the Postglacial in the Palatine Upper Rhine river floodplain. Z. Geomorph. 2009, 53, 217-245. [CrossRef]

145. Dinin, M.; Brayshay, B. The contribution of a multiproxy approach in reconstructing floodplain development. Geol. Soc. Spec. Publ. 1999, 163, 179-195. [CrossRef]

146. Ejarque, A.; Beauger, A.; Miras, Y.; Peiry, J.-L.; Voldoire, O.; Vautier, F.; Benbakkar, M.; Steiger, J. Historical fluvial palaeodynamics and multi-proxy palaeoenvironmental analyses of a palaeochannel, Allier River, France. Geodin. Acta 2015, 27, 25-47. [CrossRef]

147. Kalis, A.; Merkt, J.; Wunderlich, J. Environmental changes during the Holocene climatic optimum in central Europe-human impact and natural causes. Quat. Sci. Rev. 2003, 22, 33-79. [CrossRef]

148. Liu, X.; Jones, P.J.; Matuzeviciute, G.M.; Hunt, H.V.; Lister, D.L.; An, T.; Przelomska, N.; Kneale, C.J.; Zhao, Z.; Jones, M.K. From ecological opportunism to multi-cropping: Mapping food globalisation in prehistory. Quat. Sci. Rev. 2019, 206, 21-28. [CrossRef]

149. Stobbe, A. Die Holozäne Vegetationsgeschichte der Nördlichen Wetterau. (Dissertationes Botanicae 260), 1st ed.; Schweizerbart: Stuttgart, Germany, 1996.

150. Leibundgut, C.; Vonderstrass, I. Traditionelle Bewässerung, ein Kulturerbe Europas, 1st ed.; Merkur: Langenthal, Germany, 2016.

151. Freyhof, J. Freshwater Fish Diversity in Germany, Threats and Species Extinction. In Conservation of Freshwater Fishes: Options for the Future, 1st ed.; Collares-Pereira, M., Cowx, I.G., Coelho, M., Eds.; Wiley: Oxford, UK, 2002; pp. 3-22.

152. Bartosiewicz, L.; Bonsall, C.; Sisu, V. Sturgeon Fishing in the Middle and Lower Danube Region. In The Iron Gates in Prehistory: New Perspectives (BAR International Series 1893), 1st ed.; Bonsall, C., Boronean, V., Radovanovi, I., Eds.; Archaeopress: Oxford, UK, 2008; pp. 39-54.

153. Galik, A.; Haidvogl, G.; Bartosiewicz, L.; Guti, G.; Jungwirth, M. Fish remains as a source to reconstruct long-term changes of fish communities in the Austrian and Hungarian Danube. Aquat. Sci. 2015, 77, 337-354. [CrossRef]

154. Larsen, A.; Alvarez, N.; Sperisen, C.; Lane, S.N. Biotic drivers of river and floodplain geomorphology-New molecular methods for assessing present-day and past biota. Earth Surf. Process. Landf. 2018, 43, 333-338. [CrossRef] 
155. Haidvogl, G.; Pont, D.; Dolak, H.; Hohensinner, S. Long-term evolution of fish communities in European mountainous rivers: Past log driving effects, river management and species introduction (Salzach River, Danube). Aquat. Sci. 2015, 77, 395-410. [CrossRef]

156. Kunst, G.K.; Gemel, R. Zur Kulturgeschichte der Schildkröten unter besonderer Berücksichtigung der Bedeutung der Europäischen Sumpfschildkröte, Emys orbicularis (L.) in Österreich. Stapfia 2000, 69, 21-69.

157. Pasda, K. Tierknochen als Spiegel Sozialer Verhältnisse im 8.-15. Jahrhundert in Bayern, 1st ed.; PraeHistorika: Erlangen, Germany, 2005.

158. Mielzarek, C. Das Verschwinden der Biberpopulation an der Oder im 13. Jahrhundert. In Wassermühlen und Wassernutzung im mittelalterlichen Ostmitteleuropa, 1st ed.; Mariková, M., Zschieschang, C., Eds.; Steiner: Stuttgart, Germany, 2015 ; pp. 275-300.

159. Lampen, A. Medieval fish weirs: The archaeological and historical evidence. Archaeofauna 1996, 5, 129-134.

160. Miejac, E.; de Saulce, A.; Yeny, E. Les pêcheries de fleuves et de rivières. Aménagements médiévaux et modernes dans le centre et l'ouest de la France. In Pêches (Archéopages 26), 1st ed.; Jacob, J.P., Ed.; Inrap: Quétigny; France, 2009; pp. $38-46$.

161. Herzig, F.; Tschuch, M. Vom Wasser haben wir's gelernt. Fischen und Mahlen im mittelalterlichen Wassertrüdingen. In Das archäologische Jahr in Bayern; Archaeological Society of Bavaria: Bavaria, Germany, 2018; pp. 108-112.

162. Ansorge, J.; Frenzel, P.; Thomas, M. Cogs, Sand and Beer-A Palaeontological Analysis of Medieval Ballast Sand in the Harbour of Wismar (Southwestern Baltic Sea Coast, Germany). In Umweltarchäologie (Tagungen des Landesmuseums für Vorgeschichte Halle 6), 1st ed.; Bork, H.R., Meller, H., Gerlach, R., Eds.; Beier \& Beran: Halle, Germany, 2011; pp. 161-173.

163. Muigg, B.; Tegel, W.; Rohmer, P.; Eduard-Schmidt, U.; Büntgen, U. Dendroarchaeological evidence of early medieval water mill technology. J. Archaeol. Sci. 2018, 93, 17-25. [CrossRef]

164. Munro, J.H. Industrial energy from watermills in the European economy, 5th to 18th Centuries: The limitations of power. MPRA Paper 2002, 34, 223-269.

165. Reitemeier, A.; Petersen, N. Die Mühle und der Fluss. Juristische Wechselwirkungen. Das Mittelalter. Perspekt. Mediävistischer Forsch. 2017, 4, 276-290.

166. Gimpel, J. The Medieval Machine. The Industrial Revolution of the Middle Ages, 1st ed.; Penguin Books: London, UK, 1977.

167. Lucas, A. Wind, Water, Work. Ancient and Medieval Milling Technology (Technology and Change in History 8), 1st ed.; Brill: Leiden, The Netherlands, 2006.

168. Franzke, J. Räder im Fluß. Die Geschichte der Nürnberger Mühlen, 1st ed.; Tümmel: Nürnberg, Germany, 1986.

169. Buchty-Lemke, M.; Lehmkuhl, F. Impact of abandoned water mills on Central European foothills to lowland rivers: A reach scale example from the Wurm River, Germany. Geogr. Ann. A 2018, 100, 221-239. [CrossRef]

170. Py, V.; Véron, A.; Edouard, J.L.; de Beaulieu, J.L.; Ancel, B.; Segard, M.; Durand, A.; Leveau, P. Interdisciplinary characterisation and environmental imprints of mining and forestry in the upper Durance valley (France) during the Holocene. Quat. Int. 2014, 353, 74-97. [CrossRef]

171. Tolksdorf, J.F.; Elburg, R.; Schröder, F.; Knapp, H.; Herbig, C.; Westpfahlen, T.; Schneider, B.; Fülling, A.; Hemker, C. Forest exploitation for charcoal production and timber since the 12th century in an intact medieval mining site in the Niederpöbel Valley (Eastern Germany). J. Archaeol. Sci. Rep. 2015, 4, 487-500. [CrossRef]

172. Raab, T.; Beckmann, S.; Richard, N.; Völkel, J. Reconstruction of floodplain evolution in former mining areas-The Vils River case study. Erde 2005, 136, 47-62.

173. Buchty-Lemke, M.; Hagemann, L.; Maßß, A.L.; Schüttrumpf, H.; Schwarzbauer, J.; Lehmkuhl, F. Floodplain chronology and sedimentation rates for the past 200 years derived from trace element gradients, organic compounds, and numerical modeling. Environ. Earth Sci. 2019, 78, 445. [CrossRef]

174. Hoffmann, R.C. A brief history of aquatic resource use in medieval Europe. Helgol. Mar. Res. 2005, 59, 22-30. [CrossRef]

175. Barles, S. Urban metabolism and river systems. An historical perspective-Paris and the Seine, 1790-1970. Hydrol. Earth Syst. Sci. 2007, 11, 1757-1769. [CrossRef]

176. Kohl, W. Zur Geschichte von Gewässerverschmutzung und Gewässerschutz seit dem Spätmittelalter. Schr. Ver. Verbreit. Nat. Kennt. Wien 2002, 137-140, 223-286.

177. Jørgensen, D. Local government responses to urban river pollution in late medieval England. Water Hist. 2010, 2, 35-52. [CrossRef]

178. Delile, H.; Pleuger, E.; Blichert-Toft, J.; Goiran, J.-P.; Fagel, N.; Gadhoum, A.; Abichou, A.; Jerbania, I.B.; Fentress, E.; Wilson, A.I. Economic resilience of Carthage during the Punic Wars: Insights from sediments of the Medjerda delta around Utica (Tunisia). Proc. Natl. Acad. Sci. USA 2019, 116, 9764-9769. [CrossRef]

179. Esser, V.; Buchty-Lemke, M.; Schulte, P.; Podzun, L.S.; Lehmkuhl, F. Signatures of recent pollution profiles in comparable central European rivers. Catena 2020, 193, 104646. [CrossRef]

180. Hoffmann, R.C.; Winiwarter, V. Making land and water meet: The cycling of nutrients between fields and ponds in pre-modern Europe. Agric. Hist. 2010, 84, 352-380. [CrossRef]

181. Prell, M. Archäologie der Brücken: Vorgeschichte, Antike, Mittelalter, Neuzeit, 1st ed.; Pustet: Regensburg, Germany, 2011.

182. Logel, T. Passages à gué sur le Rhin (Alsace/Bade) au haut Moyen Âge. In Territoire Fluvial et Société au Premier Moyen Âge (Ve-XIIe Siécle), 1st ed.; Peytremann, E., Ed.; Revue Archéologique de l'est: Dijon, France, 2016; pp. 213-234.

183. Kröger, L. Crossing the River. Ferries as Part of the Maritime Landscape of the River Main (Germany). In Ships and Maritime Landscapes, 1st ed.; Gawronski, J., van Holk, A., Schokkenbroek, J., Eds.; Barkhuis: Eelde, The Netherlands, 2017 ; pp. 95-101.

184. Bundesminister für Verkehr. Steinbrücken in Deutschland, 1st ed.; Beton: Düsseldorf, Germany, 1988.

185. Harrison, D. The Bridges of Medieval England. Transport and Society 400-1800, 1st ed.; Oxford University Press: Oxford, UK, 2004. 
186. Fouquet, G. Brücken. Bau und Unterhalt im späten Mittelalter und in der frühen Neuzeit: Das Beispiel der Weidenhäuser Brücke in Marburg. In Weg und Steg: Aspekte des Verkehrswesens von der Spätantike bis zum Ende des Alten Reiches, 1st ed.; Andermann, K., Gallion, N., Eds.; Thorbecke: Ostfildern, Germany, 2018; pp. 47-73.

187. Schenk, G.J. More Resilient with Mars or Mary? Constructing a Myth and Reclaiming Public Space after the Destruction of the Old Bridge of Florence 1333. In Strategies, Dispositions and Resources of Social Resilience, 1st ed.; Endress, M., Clemens, L., Rampp, B., Eds.; Springer: Wiesbaden, Germany, 2020; pp. 139-162.

188. Feistner, E. Die Steinerne Brücke in Regensburg, 1st ed.; Schnell \& Steiner: Regensburg, Germany, 2005.

189. Gajdošová, J. The Charles Bridge: Ceremony and Propaganda in Medieval Prague, 1st ed.; Birkbeck: London, UK, 2015.

190. Gerhold, D. London Bridge and its Houses, c. 1209-1761, 1st ed.; Oxbow: London, UK, 2019.

191. Brown, S. The Medieval Exe Bridge, St. Edmund's Church, and Excavation of Waterfront Houses (Devon Archaeological Society Monograph 1), 1st ed.; Devon Archaeological Society: Exeter, UK, 2019.

192. Lübken, U. Der große Brückentod: Überschwemmungen als infrastrukturelle Konflikte im 19. und 20. Jahrhundert. Saeculum 2007, 58, 89-114. [CrossRef]

193. van de Ven, G.P. Manmade Lowlands. In History of Water Management and Land Reclamation in the Netherlands, 1st ed.; Matrijs: Utrecht, The Netherlands, 1994.

194. Groenewoudt, B.; van Doesburg, J. Medieval Reclamation and Land Use in the Netherlands. In The Archaeology of Medieval Europe, Eighth to Twelfth Centuries AD, 1st ed.; Graham-Campbell, J., Ed.; Aarhus University Press: Aarhus, Denmark, 2011; Volume 1, pp. 75-77.

195. Blackbourn, D. The Conquest of Nature: Water, Landscape and the Making of Modern Germany; Reprint; Norton: London, UK, 2007.

196. Schmid, M. Long-Term Risks of Colonization: The Bavarian 'Donaumoos'. In Social Ecology. Society-Nature Relations across Time and Space, 1st ed.; Haberl, H., Fischer-Kowalski, M., Krausmann, F., Winiwarter, V., Eds.; Springer: Cham, Germany, 2016; pp. 391-415.

197. Gläser, M. Mittelalterliche Baulandgewinnung in Lübeck. In Wasserbau in Mittelalter und Neuzeit (Mitteilungen der DGAMN 21), 1st ed.; Diener, A., Untermann, M., Eds.; Neumann: Heidelberg, Germany, 2009; pp. 59-64.

198. Sarfatij, H. Tiel und Dordrecht: Archäologie und Handel in zwei Städten im niederländischen Rheingebiet (10. bis 17. Jahrhundert). In Lübecker Kolloquium zur Stadtarchäologie im Hanseraum, 1st ed.; Gläser, M., Ed.; Schmidt-Römhild: Lübeck, Germany, 1999; Volume 2, pp. 183-200.

199. Oudhof, J.M.W.; Verhoeven, A.A.A.; Schuuring, I. Tiel rond 1000. Analyse van Vier Opgravingen in de Tielse Binnenstad, 1st ed.; Universiteit van Amsterdam: Amsterdam, The Netherlands, 2013.

200. Jenisch, B. Flutkatastrophen in mittelalterlichen Städten am südlichen Oberrhein. In Erdbeben, Feuer, Wasser und andere Katastrophen, 1st ed.; Schneller, D., Lassau, G., Möhle, M., Eds.; Gesellschaft für Schweizerische Kunstgeschichte: Bern, Switzerland, 2019.

201. Ettel, P.; Hack, A.T. (Eds.) Flusstäler, Flussschifffahrt, Flusshäfen: Befunde aus Antike und Mittelalter (RGZM Tagungen 39), 1st ed.; Schnell \& Steiner: Mainz, Germany, 2019.

202. Mirschenz, M.; Gerlach, R.; Bemmann, J.; Brosseder, U.; Joachim, H.E. (Eds.) Der Rhein als europäische Verkehrsachse III. In Bonner Beiträge zur vor- und Frühgeschichtlichen Archäologie, 1st ed.; Universität Bonn: Bonn, Germany, 2019 ; Volume 22.

203. Ellmers, D. Techniken und Organisationsformen zur Nutzung der Binnenwasserstraßen im hohen und späten Mittelalter. In Straßen- und Verkehrswesen im Hohen und Späten Mittelalter, 1st ed.; Konstanzer Arbeitskreis für mittelalterliche Geschichte, Ed.; Thorbecke: Ostfildern, Germany, 2007; pp. 161-184.

204. Eißing, T. Anlagen für den Holztransport zum, am und auf dem Fluss: Die gebundene und die ungebundene Flößerei. Forum IFL 2011, 15, 17-30.

205. Horst, T. Die Darstellung von Flüssen auf Karten des Mittelalters und der Renaissance: Ein Überblick. In Flusstäler, Flussschifffahrt, Flusshäfen: Befunde aus Antike und Mittelalter (RGZM Tagungen 39), 1st ed.; Ettel, P., Hack, A., Eds.; Schnell \& Steiner: Mainz, Germany, 2019; pp. 139-158.

206. Mehler, N. Marine Trade and Transport Related Crafts and their Actors: People without Archaeology? In Everyday Products in the Middle Ages: Crafts, Consumption and the Individual in Northern Europe c. 800-1600, 1st ed.; Hansen, G., Ashby, S., Baug, I., Eds.; Oxbow Books: Oxford, UK, 2015; pp. 360-375.

207. Brandl, M.; Martinez, M.M.; Hauzenberger, C.; Filzmoser, P.; Nymoen, P.; Mehler, N. A multi-technique analytical approach to sourcing Scandinavian flint: Provenance of ballast flint from the shipwreck 'Leirvigen 1'. PLoS ONE 2018, 13, e0200647. [CrossRef]

208. Brock, A. Floodplain occupation and landscape modification in early Rome. Quat. Int. 2017, 460, 167-174. [CrossRef]

209. Hoffmann, R.C. Economic development and aquatic ecosystems in medieval Europe. Am. Hist. Rev. 1996, 101, 631-669. [CrossRef]

210. Milne, G. Timber Building Techniques in London, c 900-1400: An Archaeological Study of Waterfront Installations and Related Material (London and Middlesex Archaeological Society Special Paper 15), 1st ed.; The Museum of London and the London \& Middlesex Archaeological Society: London, UK, 1992.

211. Wollenberg, D.; Nießen, I. How to Identify a Harbour in the Archaeological Record in Medieval Urban Contexts? A Case Study of Regensburg, Frankfurt/Main and Speyer. In Inland Harbours in Central Europe: Nodes between Northern Europe and the Mediterranean Sea (RGZM Tagungen), 1st ed.; Foucher, M., Dumont, A., Werther, L., Wollenberg, D., Eds.; Schnell \& Steiner: Mainz, Germany, 2019; Volume 38, pp. 141-164.

212. Fournier, P.; Lavaud, S. (Eds.) Eaux et Conflits Dans l'Europe Médiévale et Moderne, 1st ed.; Presses Universitaires du Mirail: Toulouse, France, 2012. 
213. Magnusson, R.J. Water Technology in the Middle Ages: Cities, Monasteries, and Waterworks after the Roman Empire, 1st ed.; Johns Hopkins University Press: Baltimore, MD, USA, 2001.

214. Vadas, A. Border by the river-But where is the river? Hydrological changes and borders in Medieval Hungary. Hung. Hist. Rev. 2019, 8, 336-360.

215. Getzler, J. A History of Water Rights at Common Law, 1st ed.; Oxford University Press: Oxford, UK, 2004.

216. Menotti, F.; O'Sullivan, A. (Eds.) The Oxford Handbook of Wetland Archaeology, 1st ed.; Oxford University Press: Oxford, UK, 2013.

217. Hausmann, J.; Zielhofer, C.; Berg-Hobohm, S.; Dietrich, P.; Heymann, R.; Werban, U.; Werther, L. Direct push sensing in wetland (geo)archaeology: High-resolution reconstruction of buried canal structures (Fossa Carolina, Germany). Quat. Int. 2018, 473, 21-36. [CrossRef]

218. Zielhofer, C.; Rabbel, W.; Wunderlich, T.; Vött, A.; Berg, S. Integrated geophysical and (geo)archaeological explorations in wetlands. Quat. Int. 2018, 473, 1-2. [CrossRef]

219. Notebaert, B.; Verstraeten, G.; Govers, G.; Poesen, J. Qualitative and quantitative applications of LiDAR imagery in fluvial geomorphology. Earth Surf. Process. Landf. 2008, 34, 217-231. [CrossRef]

220. Schmidt, J.; Werther, L.; Zielhofer, C. Shaping pre-modern digital terrain models: The former topography at Charlemagne's canal construction site. PLOS ONE 2018, 13, e0200167. [CrossRef]

221. Schmidt, J.; Völlmer, J.; Werther, L.; Werban, U.; Dietrich, P.; Berg, S.; Ettel, P.; Linzen, S.; Stele, A.; Zielhofer, C. 3D modelling of Charlemagne's summit canal (SW Germany)_merging remote sensing and geoarchaeological subsurface data. Remote Sens. 2019, 11, 1111. [CrossRef]

222. van der Meulen, B.; Cohen, K.M.; Pierik, H.J.; Zinsmeister, J.J.; Middelkoop, H. LiDAR-derived high-resolution palaeo-DEM construction workflow and application to the early medieval Lower Rhine valley and upper delta. Geomorphology 2020, 370, 107370. [CrossRef]

223. Rabiger-Völlmer, J.; Schmidt, J.; Linzen, S.; Werban, U.; Dietrich, P.; Wilken, D.; Wunderlich, T.; Berg, S.; Werther, L.; Zielhofer, C. Non-invasive prospection techniques and direct push sensing as high-resolution validation tools in wetland geoarchaeology. $J$. Appl. Geophy. 2020, 173, 103928. [CrossRef]

224. Fischer, P.; Wunderlich, T.; Rabbel, W.; Vött, A.; Willershäuser, T.; Baika, K.; Rigakou, D.; Metallinou, G. Combined electrical resistivity tomography (ERT), direct-push electrical conductivity (DP-EC) logging and coring-A new methodological approach. Archaeol. Prospect. 2016, 23, 213-228. [CrossRef]

225. Kirchner, A.; Zielhofer, C.; Werther, L.; Schneider, M.; Linzen, S.; Wilken, D.; Wunderlich, T.; Rabbel, W.; Meyer, C.; Schmidt, J.; et al. A multidisciplinary approach in wetland (geo)archaeology: Survey of the missing southern canal connection of the Fossa Carolina (SW Germany). Quat. Int. 2018, 473, 3-20. [CrossRef]

226. Reischer, M.; Christensen, A.G.; De Weirdt, F.; Bruns, S.; Dideriksen, K. Capabilities of an optical direct push probe for 2Dsubsurface imaging. J. Contam. Hydrol. 2020, 232, 103636. [CrossRef] [PubMed]

227. Wunderlich, T.; Wilken, D.; Erkul, E.; Rabbel, W.; Vött, A.; Fischer, P.; Hadler, H.; Heinzelmann, M. The river harbour of Ostia Antica-Stratigraphy, extent and harbour infrastructure from combined geophysical measurements and drillings. Quat. Int. 2018, 473, 55-65. [CrossRef]

228. Brisset, E.; Guiter, F.; Miramont, C.; Troussier, T.; Sabatier, P.; Poher, Y.; Cartier, R.; Arnaud, F.; Malet, E.; Anthony, E.J. The overlooked human influence in historic and prehistoric floods in the European Alps. Geology 2017, 45, 347-350. [CrossRef]

229. Oksanen, E. Inland Navigation in England and Wales Before AD 1348 (GIS Database); Archaeology Data Service: York, UK, 2019. [CrossRef]

230. van Lanen, R.J.; Kosian, M.C. What wetlands can teach us: Reconstructing historical water-management systems and their present-day importance through GIScience. Water Hist. 2020, 12, 151-177. [CrossRef]

231. Sonnlechner, C.; Hohensinner, S.; Haidvogl, G. Floods, fights and a fluid river. The Viennese Danube in the sixteenth century. Water Hist. 2013, 5, 173-194. [CrossRef]

232. Werther, L. Komplexe Systeme im Diachronen Vergleich. Ausgewählte Aspekte der Entwicklung von drei Süddeutschen Kleinräumen Zwischen Früh- und Hochmittelalter (RGZM Monographien 127), 1st ed.; Schnell \& Steiner: Regensburg, Germany, 2015.

233. Engel, T.; Kunz, A.; Müller, H.; Werther, L. Towards a Virtual Research Environment for Ancient Harbour Data. In Harbours as Objects of Interdisciplinary Research-Archaeology + History + Geoscience (RGZM Tagungen 34), 1st ed.; Daim, F., von CarnapBornheim, C., Ettel, P., Warnke, U., Eds.; Schnell \& Steiner: Mainz, Germany, 2018; pp. 59-69.

234. Hoffmann, T.; Erkens, G.; Cohen, K.M.; Houben, P.; Seidel, J.; Dikau, R. Holocene floodplain sediment storage and hillslope erosion within the Rhine catchment. Holocene 2007, 17, 105-118. [CrossRef]

235. Hijma, M.; Cohen, K.M. Holocene transgression of the Rhine river mouth area, The Netherlands/Southern North Sea: Palaeogeography and sequence stratigraphy. Sedimentology 2011, 58, 1453-1485. [CrossRef]

236. Haidvogl, G.; Guthyne-Horvath, M.; Gierlinger, S.; Hohensinner, S.; Sonnlechner, C. Urban land for a growing city at the banks of a moving river. Vienna's spread into the Danube island Unterer Werd from the late 17th to the beginning of the 20th century. Water Hist. 2013, 5, 195-217. [CrossRef]

237. Schlummer, M.; Hoffmann, T.; Dikau, R.; Eickmeier, M.; Fischer, P.; Gerlach, R.; Holzkämpfer, J.; Kalis, A.J.; Kretschmer, I.; Lauer, F.; et al. Upscaling approaches for late Quaternary archaeological and environmental data. Earth-Sci. Rev. 2014, 131, 22-48. [CrossRef] 
238. Frings, R.M.; Hillebrand, G.; Gehres, N.; Banhold, K.; Schriever, S.; Hoffmann, T. From source to mouth: Basin-scale morphodynamics of the Rhine River. Earth-Sci. Rev. 2019, 196, 102830. [CrossRef]

239. Cooper, A.; Green, C. Embracing the complexities of 'big data' in archaeology: The case of the English Landscape and Identities project. J. Archaeol. Method Theory 2015, 23, 271-304. [CrossRef]

240. McCoy, M. Geospatial big data and archaeology: Prospects and problems too great to ignore. J. Archaeol. Sci. 2017, 84, 74-94. [CrossRef]

241. Werther, L.; Kröger, L. Medieval inland navigation and the shifting fluvial landscape between Rhine and Danube (Germany). Post Class. Archaeol. 2017, 7, 65-96.

242. Werther, L.; Foucher, M.; Müller, H. (Eds.) European Harbour Data Repository. Digital Library Thuringia, 2018-2020. Available online: https: / / www.db-thueringen.de/receive/dbt_mods_00035240 (accessed on 7 June 2021).

243. Doi, H.; Inui, R.; Akanatsu, Y.; Kanno, K.; Yamanaka, H.; Takahara, T.; Minamoto, T. Environmental DNA analysis for estimating the abundance and biomass of stream fish. Freshw. Biol. 2017, 62, 30-39. [CrossRef]

244. Kuwae, M.; Tamai, H.; Doi, H.; Sakata, M.K.; Minamoto, T.; Suzuki, Y. Sedimentary DNA tracks decadal-centennial changes in fish abundance. Commun. Biol. 2020, 3, 558. [CrossRef]

245. Domaizon, I.; Winegardner, A.; Capo, E.; Gauthier, J.; Gregory-Eaves, I. DNA-based methods in paleolimnology: New opportunities for investigating long-term dynamics of lacustrine biodiversity. J. Paleolimnol. 2017, 58, 1-21. [CrossRef]

246. Capo, E.; Giguet-Covex, C.; Rouillard, A.; Nota, K.; Heintzman, P.D.; Vuillemin, A.; Ariztegui, D.; Arnaud, F.; Belle, S.; Bertilsson, S.; et al. Lake sedimentary DNA research on past terrestrial and aquatic biodiversity: Overview and recommendations. Quat. Int. 2021, 4, 6 .

247. Clarke, C.L.; Edwards, M.E.; Brown, A.G.; Gielly, L.; Lammers, Y.; Heintzman, P.D.; Ancin-Murguzur, F.J.; Bråthen, K.-A.; Goslar, T.; Alsos, I.G. Holocene floristic diversity and richness in Northeast Norway revealed by sedimentary ancient DNA and pollen. Boreas 2018, 48, 299-316. [CrossRef]

248. Matisoo-Smith, E.; Roberts, K.; Welikala, N.; Tannock, G.; Chester, P.; Feek, D.; Flenley, J. Recovery of DNA and pollen from New Zealand lake sediments. Quat. Int. 2008, 184, 139-149. [CrossRef]

249. Stager, J.C.; Sporn, L.A.; Johnson, M.; Regalado, S. Of paleo-genes and Perch: What if an 'Alien' is actually a native? PLoS ONE 2015, 10, e0119071. [CrossRef] [PubMed]

250. Flammer, P.G.; Dellicour, S.; Preston, S.G.; Rieger, D.; Warren, S.; Tan, C.K.W.; Nicholson, R.; Přichystalová, R.; Bleicher, N.; Wahl, J.; et al. Molecular archaeoparasitology identifies cultural changes in the medieval Hanseatic trading centre of Lübeck. Proc. Royal Soc. B 2018, 285, 20180991. [CrossRef]

251. Briggs, L. Ancient DNA research in maritime and underwater archaeology: Pitfalls, promise and future directions. Open Quat. 2020, 6, 3. [CrossRef]

252. Star, B.; Boessenkool, S.; Gondek, A.T.; Nikolina, E.A.; Hufthammer, A.K.; Pampoulie, C.; Knutsen, H.; André, C.; Nistelberger, H.M.; Dierking, J.; et al. Ancient DNA reveals the Arctic origin of Viking Age cod from Haithabu, Germany. Proc. Natl. Acad. Sci. USA 2017, 114, 9152-9157. [CrossRef]

253. Živaljević, I.; Popović, D.; Snoj, A.; Marić, A.S. Ancient DNA analysis of cyprinid remains from the Mesolithic-Neolithic Danube Gorges reveals an extirpated fish species Rutilus frisii (Nordmann, 1840). J. Archaeol. Sci. 2017, 79, 1-9. [CrossRef]

254. Tarolli, P.; Sofia, G. Human topographic signatures and derived geomorphic processes across landscapes. Geomorphology 2016, 255, 140-161. [CrossRef]

255. Hooke, R.L.; Martín-Duque, J.F. Land transformation by humans. A review. GSA Today 2012, 12, 4-10. [CrossRef]

256. Foley, S.F.; Gronenborn, D.; Andreae, M.O.; Kadereit, J.W.; Esper, J.; Scholz, D.; Pöschl, U.; Jacob, D.E.; Schöne, B.R.; Schreg, R.; et al. The Palaeoanthropocene-The beginnings of anthropogenic environmental change. Anthropocene 2013, 3, 83-88. [CrossRef]

257. Fuller, I.C.; Macklin, M.G.; Richardson, J.M. The geography of the Anthropocene in New Zealand: Differential river catchment response to human impact. Geogr. Res. 2015, 53, 255-269. [CrossRef]

258. Brown, A.G.; Tooth, S.; Bullard, J.E.; Thomas, D.S.G.; Chiverrell, R.C.; Plater, A.J.; Murton, J.; Thorndycraft, V.R.; Tarolli, P.; Rose, J.; et al. The geomorphology of the Anthropocene: Emergence, status and implications. Earth Surf. Process. Landf. 2016, 42, 71-90. [CrossRef]

259. Kelly, J.M.; Scarpino, P.V.; Berry, H.; Syvitski, J.; Meybeck, M. (Eds.) Rivers of the Anthropocene, 1st ed.; University of California Press: Oakland, CA, USA, 2018.

260. Lewin, J.; Macklin, M.G. Floodplain catastrophes in the UK Holocene: Messages for managing climatic change. Hydrol. Process. 2010, 24, 2900-2911. [CrossRef]

261. Leopold, L.B.; Wolman, M.G. River channel patterns: Braided, meandering and straight. Geol. Surv. Prof. Pap. $1957,282,1-85$.

262. River Restoration Centre. Handbook of River Restoration Techniques. 2020. Available online: https://www.therrc.co.uk/manualriver-restoration-techniques (accessed on 8 June 2021).

263. Kondolf, M. River restoration and meanders. Ecol. Soc. 2006, 11, 42. [CrossRef] 
264. Moss, T.; Monstadt, J. Restoring Floodplains in Europe, 1st ed.; IWA Publishing: London, UK, 2008.

265. Hein, T.; Funk, A.; Pletterbauer, F.; Graf, W.; Zsuffa, I.; Haidvogel, G.; Schinegger, R.; Weigelhöfer, G. Management challenges related to long-term ecological impacts, complex stressor interactions, and different assessment approaches in the Danube River Basin. River Res. Appl. 2019, 35, 500-509. [CrossRef] 